8-1-1965

\title{
Effects of Surface-Active Agents on the Susceptibility of Swiss Mice to Candida Albicans
}

Harvey W. Holm

How does access to this work benefit you? Let us know!

Follow this and additional works at: https://commons.und.edu/theses

\section{Recommended Citation}

Holm, Harvey W., "Effects of Surface-Active Agents on the Susceptibility of Swiss Mice to Candida Albicans" (1965). Theses and Dissertations. 3869.

https://commons.und.edu/theses/3869

This Thesis is brought to you for free and open access by the Theses, Dissertations, and Senior Projects at UND Scholarly Commons. It has been accepted for inclusion in Theses and Dissertations by an authorized administrator of UND Scholarly Commons. For more information, please contact und.commons@library.und.edu. 
EFFECTS OF SURFACE-ACTIVE AGENTS ON THE SUSCEPTIBILITY OF SWISS MICE TO CANDIOA ALBICANS

\section{By}

Harvey W. Holm

B.S. In Biology. Minot state College 1963

\section{A Thesis}

Submitted to the Faculty

$$
\text { of the }
$$

University of North Dakota

in partial fulfillment of the requirements

$$
\text { for the Degree of }
$$

$$
\text { Master of Science }
$$

Grand Forks, North Dakota 
This thesis submitted by Harvey W. Holm in partial fulfilliment of the requirements for the Degree of Master of Science in the University of North Dakota, is hereby approved by the Committee under whom the work has been done.
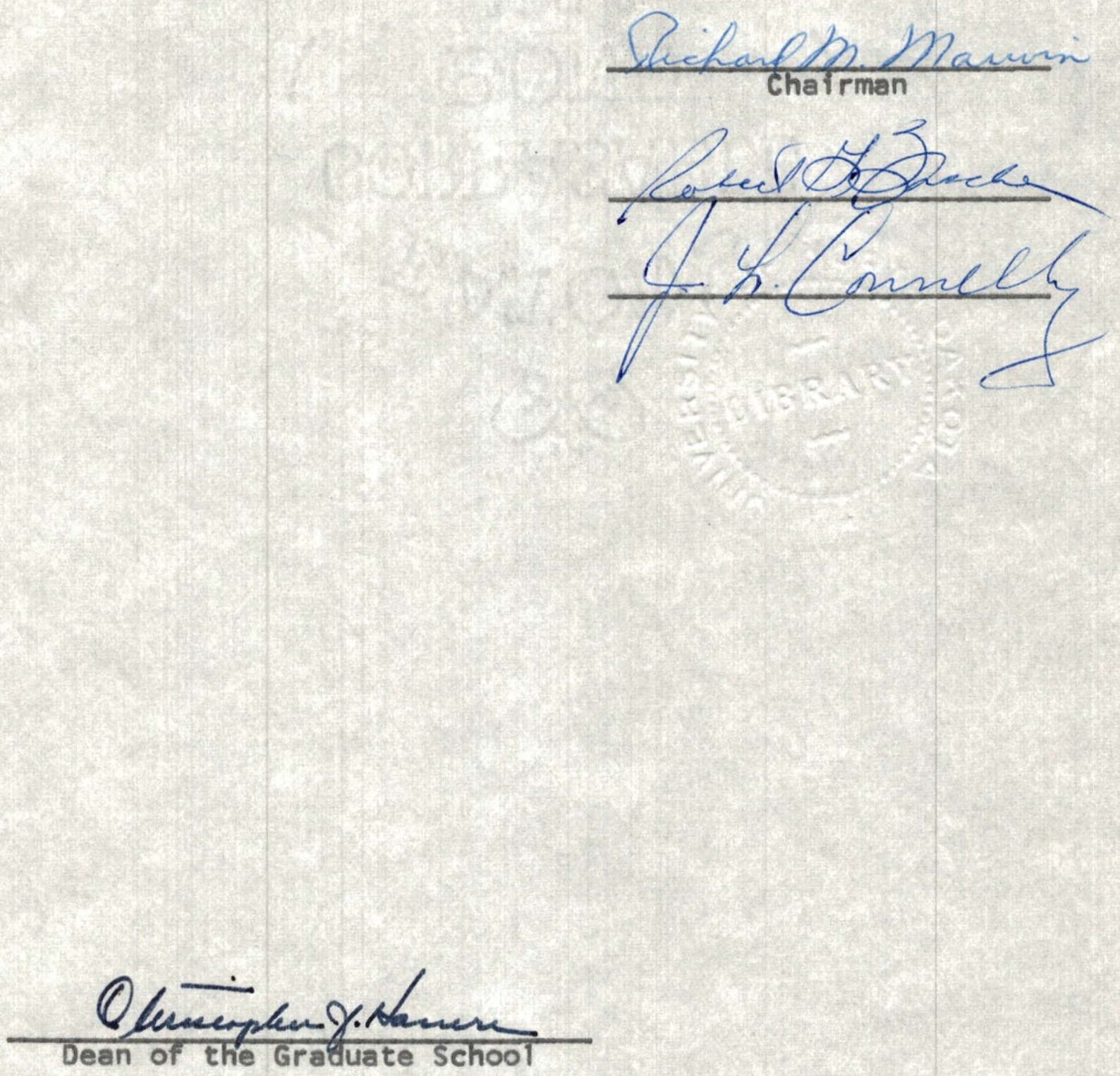
ABSTRACT

EFFECTS OF SURFACE-ACTIVE AGENTS ON THE

SUSCEPTIBILITY OF SWISS MICE TO GANDIDA ALBICANS

Harvey W. Holm, Master of Science

The thesis here abstracted was written under the direction of Dr. Richard M. Marwin and approved by Or. Robert G. Fischer and Dr. Jerald L. Connelly as members of the examing committee of which Dr. Marwin was Chairman.

White Swiss mice are generally resistant to Candida albicans injected intraperitoneally. An effort was made to determine if surfactants when combined with Candida albicans would decrease the LD50 of this organism. The surfactants tested were Plurafac B26, Polyethylene Glycol 400 Mono Laurate, Mulsor 224, and Pluronic L62.

Peritoneal leukocyte and differential counts, tissue sections, and blood cultures were done to determine the action of surfactants.

The following conclusions were made:

(a) Plurafac B26, Polyethylene G1ycol 400 Mono Laurate, Pluronic L62, and Mulsor 224 increase mouse susceptibility to Candida al- 


\section{bicans.}

(b) The degree of susceptibility enhancement varles among the surfactants tested.

(c) Plurafac B26 inftially destroys leukocytes in the peritoneal cavity.

(d) Massive invasion of the pancreas may be the cause of death of animals given a Candida albicans - surfactant combination intraperitoneally.

The results suggest that surfactants may be a diagnostic tool of value in enhancing mouse susceptibillty to Candida albicans. 
This abstract of a thesis submitted by Marvey W. Holm in partial fulfillment of the requirements for the Degree of Master of Science in the University of North Dakota, is hereby approved by the Committee under whom the work has been done.
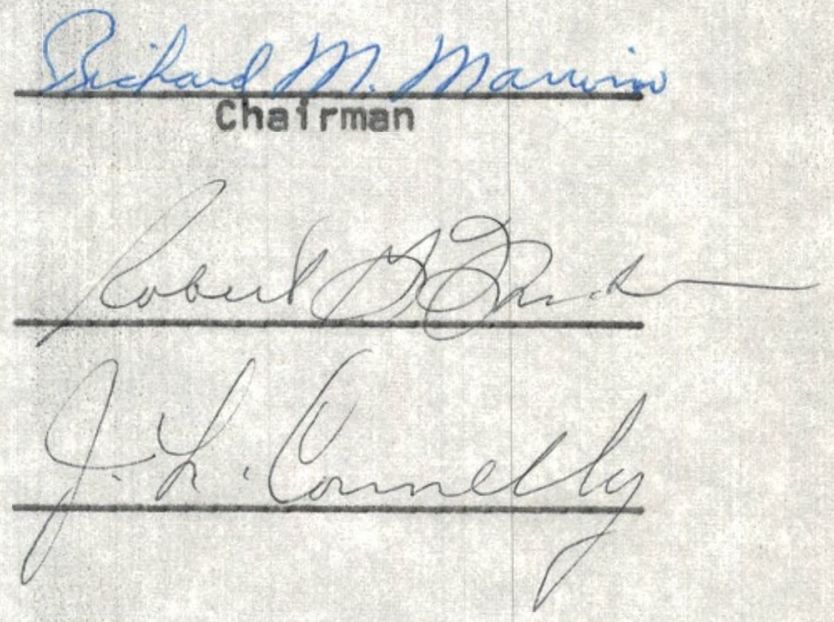


\section{ACKNOWLEDGEMENTS}

The author wishes to thank Dr. Richard M. Marwin for his encouragement and guidance during the course of this investigation. A thank you is also given to Dr. Robert G. Fischer for his helpful advice.

A special thank you goes to Karyn Paupst for her patience in the typing of this thesis.

Acknowledgements aiso go to the Pathology Department at the University of North Dakote School of Medicine for the preparation of the tissue sections and to Mr. Eugene Holweger for the preparation of the plates. 
LIST OF TABLES . . . . . . . . . . . .

LIST OF ILLUSTRATIONS .............

I. INTRODUCTION. . .............

Susceptibility of Laboratory Animais to

$$
\text { Candida a.loicans }
$$

Attempts to Increase Mouse Susceptibility to Candida albicans
surface-Active Agents

The Role of Surface-Active Agents in Biology Purpose of Research

II. MATERIALS .................

Organisms

Media

Surface-Active Agents

Mice

Equipment:

III. METHODS ..................

Effect of Surface-Active Agents

Characteristics of Candida albicans

Preparation of the Organisms

Experimental Procedures

Determination of LD50

IV. RESULTS. ............... 24

V. DISCUSSION.......................... 65

VI. SUMMARY .......................... 73

LITERATURE CITED ............... 75 


\section{LIST OF TABLES}

Table

1. Lethality of various concentrations of surfactants injected intraperitoneally in 0.5 $\mathrm{ml}$ volumes. ...............

2. Fatalities of female Swiss mice injected with varying amounts of Candida albicans - Series I................

3. Fatalities of female Swiss mice injected with varying amounts of Candida albicans - Series II. ................ 28

4. Fatalities of female Swiss mice injected with Candida albicans and varying percentages of Plurafac B26 - Series I...........

5. Fatalities of female Swiss mice injected with Candida albicans and varying percentages of PTurafac 826 - Series II. . . . .......

6. Fatalities of female Swiss mice injected with Candida albicans and varying percentages of Polyethylene GIycol 400 Mono Laurate - Series I...................

7. Fatalities of female Swiss mice injected with Candida albicans and varying percentages of Polyethylene Glycol 400 Mono Laurate - Series II.

8. Fatalities of female Swiss mice injected with Candida albicans and varying percentages of Mulsor 224.................

9. Fatalities of female Swiss mice injected with Candida albicans and varying percentages of pluronic L62................

10. Fatalities of female Swiss mice injected with 1.0 per cent Plurafac B26 and varying numbers of Candida albicans - Series I..... 
11. Fatalities of female Swiss mice injected with 1.0 per cent Plurafac $B 26$ and varying numbers of Candida albicans - Series II. . . . 36

12. Fatailties of female Swiss mice injected with 1.0 per cent Polyethylene Glycol 400 Mono Laurate and varying numbers of Candida albicans - Series I............. 37

13. Fatalities of female suiss mice injected with 1.0 per cent Polyethylene Glycol 400 Mono Laurate and varying numbers of Candida albicans - Series 1 1. ........... 38

14. Fatalities of female Swiss mice infected with 1.0 per cent Pluronic L62 and varying numbers of Candida albicans ..........

15. Fatalities of female Swiss mice injected with 1.0 per cent Mulsor 224 and varying numbers of Candida alblcans . . . . . . . . . .

16. Summary of Tables 2, 3, and 10--15. L.050's of 1.0 per cent surfactants combined with Candida albicans. dilutions of 104, 105, 106 , TOT, and 108\%..............

17. Summary of Tables 4--9. L.050's of $2 \times 10^{7}$ Candida albicans combined with surfactant dTutons of 0.25 per cent, 0.5 per cent, 0.75 per cent, and 1.0 per cent .......

18. Fatalities of fenale Swiss mice injected with varying numbers of Candida albicans grown in Muisor 224 - Sabouraud Tiquid medium. . . . .

19. Fatalities of female Swiss mice injected with varying numbers of Candida albicans grown in Polyethylene Giycol 400 Mono Laurate - Sabouraud liquid medi um. ............

20. Leukocyte response in mice 3 hours after intraperitoneal injection of Candide albicans and 1.0 per cent Plurafac B26 - Candida albicans 
21. Leukocyte response in mice 5 hours after intraperitoneal injection of Candida albicans and 1.0 per cent Plurafac B26 - Candida albicans. .............. 49-50

22. Leukocyte recovered from intraperitoneal cavities of mice injected with Candida albicans and 1.0 per cent Plurafac 826 - Candida atbicans................. 52

23. Invasion of panereas and kidneys of white Swiss mice by Candida albicans ....... 62

24. Tall and heart blood cultures of Candida albicans and Plurafac 826 - Candida albicans

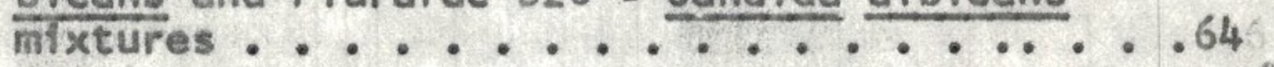




\section{LIST OF ILLUSTRATIONS}

Plate

Page

1. Section of a normal white Swiss mouse kidney. (X100; periodic acid - Schiff method)

2. Section of a normal white Swiss mouse pancreas. (X100; periodic acid - Schiff method)

3. Invasion of pancreas by Candida albicans suspended in 1.0 per cent Plurafac 826. ( $\times 450$; periodic acid - Schiff method)

4. Destruction of pancreas by Candida albicans suspended in 1.0 per cent plurafac $B 26$. 24 hour infection ( $\times 100$; periodic acid Schiff method)

5. Invasion of connective tissue near the pancreas 24 hours after intraperitoneal injection of $2 \times 10^{7}$ Candida albicans. ( $\times 450$; periodic acid - Schiff method)

6. Massive invasion of pancreas 24 hours after intraperitoneal injection of $6.7 \times 10^{8}$ Candida albicans. ( $\times 450$; periodic acid - Schiff method)

7. Typical lesion of kidney 24 hours after intraperitoneal injection of $6.7 \times 10^{8}$ Candida albicans. ( $x 100$; periodic acid - Schiff method)

8. Spreading hyphae in kidneys 24 hours after intraperitoneal injection with $6.7 \times 10^{8}$ Candida albicans: ( $x 450$; periodic acid Schiff method) 


\section{EFFECTS OF SURFACE-ACTIVE AGENTS ON THE SUSCEPTIBILITY}

OF SWISS MICE TO CANOIDA ALBICANS 


\section{INTRODUCTION}

Susceptibility of Laboratory Animals to Candida albicans

The laboratory mouse is cormonly the animal of cholce for pathogenic and therapeutic studies. If the mouse responds equally as favorably as other laboratory animais in a given situation, it is generally used. The size of the mouse dictates its use because of space, expense, and availability factors. However, there are instances when the laboratory mouse is not as susceptible to an infectious organism as another laboratory animal. Early studies by Benham in 1931 showed that the rabbit was readily susceptible to Candida albicans while the mouse was considered resistant (1). She injected Candida albicans microorganisms intravenously into rabbits; death occurred with in four or five days. Stovall and Pessin, in a paper published in 1934, observed that Candida albicans produced death or extensive lesions when 0.5 1.5 million cells/100 grams of body weight were injected intravenously into rabbits, but other species of Candida required many more organisms per 100 grams of body weight to cause injury or death (2).

In 1951 Fuentes et a1. studied the pathogenicity 
of Candida albicans in laboratory animais (3). One million microorganisms/100 grams of body weight were injected intravenously into rats, mice, rabbits, and guinea pigs. The most susceptible animal appeared to be the rat, followed by the rabbit, the guinea pig, and the mouse. The average survival time was 5 days for rats and rabbits, 11 days for guinea pigs, and 15 days for mice.

Later papers demonstrated that mice were susceptible to Candida albicans. In 1954, Solotorovsky showed that white Swiss laboratory mice were susceptible to Candida albicans given intravenously (4). A later work by Mankowski reported that $4 \times 10^{6}$ Candida albicans organisms injected intravenously killed nearly all of the mice injected within 3 days, whereas the same number of Candida albicans organisms injected intraperitoneally were generally non-pathogenic for white Swiss mice (5). He al so observed that other species of Candida were usually less pathogenic than Candida albicans.

Hasenclever, through his extensive study made in 1959. reported that the relative susceptibility of mice and rabbits to candidiasis was about equal (6). The number of organisms received by each animal intravenously 
was dependent upon the weight of the animal. Hasenclever stated that the reason rabbits were previously considered susceptible to Candida albicans, and mice were not, was that in the original work rabbits were injected intravenously and mice were injected intraperitoneally. This work also showed that pathogenicity varied with each strain of Candida albicans.

Candida albicans organisms have also been injected intravenousiy into guinea pigs. Winner, in 1960, found that guinea pigs infect with Candida albicans died as a result of acute pulmonary changes (7): No study of comparative pathogenicity of Candida albicans for mice and guinea pigs was made:

Generally, there is a lack of information of pathogenicity of Candide albicans for laboratory animals. No extensive work with L050's has been done. Attempts to Increase Mouse Susceptibility to Candida albicans

Although Hasenclever showed that under proper conditions the Swiss mouse and the rabbit were equally susceptible to Candida albicans injected intravenously, a large number of organisms was a prerequisite of infection (8). The ideal situation would be to have a lowered LD50 of Candidar albteans when injected intraperitoneally. (The 
intraperitoneal injection is generally favored by laboratory personnel because of the simplicity of execution).

One of the initial substances used to increase the susceptibility of mice to infectious agents was mucin. Mankowski showed that the virulence-enhancing power of mucin greatly decreases as the percentage of mucin was lowered from 10 per cent to 1.5 per cent (9). He suggested using a 5 per cent mucin solution for maximum efficiency.

In 1951 Salvin et al. reported on the use of 2.5 per cent gastric mucin to produce high rates of infection and mortality in white Swiss mice injected with Candida al bicans $(10)$. This work showed that the intracerebral route of injection was the most effective, and the subcutaneous route was the least effective. The intraperitoneal route was intermediate in its effect. Strauss and $\mathrm{Kligman}$, who also showed that gastric mucin lowered the resistance of mice to Candida albicans, suggested that gastric mucin might be of great value in the study of deep-seated mycoses (11).

Certain antibiotics have also been used to increase animal susceptibility to fungus infections. Seligmann, in 1953, found that Candida albicans mixed with either aureo- 
mycin or terramycin produced increased fatalities in mice (12). Others confirmed this work (13). Another substance, cortisone, has been shown to increase the susceptibility of mice to Candida albicans. Seligmann showed that intraperitoneal injections of cortisone increased the death rate when mice were challenged with Candida albicans (14). All other routes of administration with cortisone did not increase mouse susceptibility. Louria et al. In 1960, also showed that cortisone increased the rate of infection in mice by Candida albicans (15). In 1957 Roth et al. found that pre-treatment of mice with roentgen radiation and cortisone, given either singly or in combination, reduced resistance to Candida albicans (16). They explained the action of radiation as one or a combination of the following: (a) inhibiton of the inflamnatory resonse, (b) inhibiton of the immune response, (c) impairment of the reticulo-endothelial system, or (d) a direct effect upon the invading pathogen. They suggested that cortisone inhibited the inflamnatory response. Surface-Active Agents

Another special group of compounds has been found to have varied effects on biological systems. These compounds are known as surface-active agents, surfactants, detergents, syndets, surface tension depressants, or wet- 
ting agents. Schwartz (17) characterized these compounds In the following manner:
"Certain solutes, even when present in very low concentration, have the start- ling property of altering the surface energy of their solvents to an extreme degree. The effect is invariably a lowering rather than an increase of the surface energy. Solutes having such properties have come to be known as the surface-active agents, and their unusual effect is known as surface activity."

Surfactant molecules are composed of two portions: a non-polar end that is not soluble in water (hydrophobic), and a polar end that is soluble in water (hydrophilic) (18). The non-polar portions of the molecule may be straight, branched, or cyclle saturated hydrocarbons; or they may be aromatic hydrocarbons such as benzene and napthalene (19).

The hydrophilic portion of the surfactant molecule may be efther fonic or non-ionic. The active groups of ionic detergents may be anionic $\left(-\mathrm{COO}^{-}-\mathrm{OSO}_{2} \mathrm{O}^{-}\right.$or $\left.-\mathrm{SO}_{2} \mathrm{O}_{-}^{-}\right)$

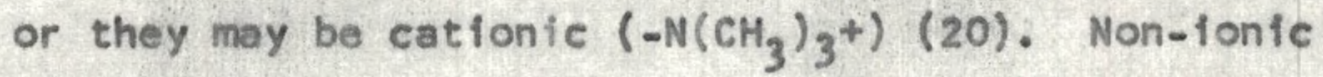
detergents have non-ionizable high affinity end groups usually containing oxygen, nitrogen, or sulfur atoms in non-ionizing configurations. Generally, it is unusual to have non-ionic substances other than hydroxyl and ether groups occurring in sufficient numbers to make the molecule soluble in water (21). 
Modern synthetic methods allow the introduction of controlled numbers of ether or hydroxyl molecules into a hydrophobic molecule. An example showing how to produce Ionic surface-active agents is as follows: A hydrophobic hydroxyl compound (phenol or alcohol) combines with several moles of ethylene oxide or propylene oxide (22).

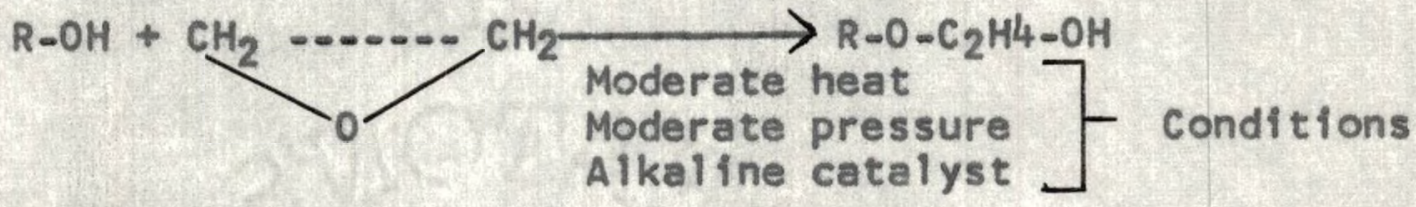

The number of ethylene oxide groups needed depends on the molecular weight of the hydrophobic portion of the molecule (23).

The Role of Surface-Active Agents in Biology

Surfactants have been found to have diversified applications to microbiology. Some of the properties of certain surfactants are as follows:

(a) Surfactants increase the rate of growth of certain bacteria in culture media $(24,25)$.

(b) Surfactants inhibit bacterial growth $(26,27)$.

(c) Surfactants clear (semi-digest) scales, hair, and nall scrapings to aid identification of fungi by slide preparations $(28)$.

(d) Surfactants inhibit bacterial metabolism $(29,30)$. 
(e) Surfactants increase the actions of bactericidal substances $(31)$.

(f) Surfactants increase the rate of growth of fungi in culture media $(32,33)$.

(g) Surfactants increase the susceptibility of laboratory animals to microbial infections.: Christovao, in 1957, showed that Deceresol-or and sodium lauryl sulfate enhanced the pathogenicity of Shigella dysenteriae, Shigella paradysenteriae, and Salmonella typhosa (34). A study by Amsterdam and Schneierson compared the actions of bile salts and the surfaceactive agents Naccosal A, Aerosol MA, Triton $X-100$, and Tween 80 to gastric mucin (35). They used several different genera of bacteria and the fungus Candida Albicans. Amsterdam and Schneierson found that surfactants increased the susceptibility of mice to these microorganisms.

The effects of surface-active agents on animal tissues have been briefly studied. Goldhammer and McManus, in an in vivo study, found that $0.1 \mathrm{ml}$ of certain surfactants, when placed on the surface of the liver and 
kidneys of rats and mice, caused the deaths of the majority of the animals $(36)$.

Nissim studied the actions of some surface-active agents on the gastro-intestinal mucosa (37). He observed that small doses of cationic compounds killed laboratory mice. Hemorrhages at the pyloric portion of the intestine, the duodenum, the jejunum, and the lleum were seen. Large doses of the anionic compound, sodium lauryl sulphate, given intraperitoneally killed laboratory animals, but no pathologic abnormalities were observed. NonIonic compounds did not affect the laboratory mice.

Surface-active agents also affect phagocytic rates. In 1949, Berry et al. (In an in vitro study) found that 5 of 52 surface-active agents doubled the number of bacteria ingested per human neutrophile compared to control values (38). They mentioned, however, that some surface-active agents depressed phagocytosis.

Another study by Di Luzio and Wooles in 1964 showed that the phagocytic activity of the reticuloendothelial system is depressed by methyl palmitate (39). Purpose of Research

Generally man, not unlike the laboratory mouse, is somewhat resistant to Candida albicans infections. 
However, if the condition of the host is impaired or altered, he is more susceptible to candidiasis. For example, if man receives extensive antibiotic therapy, candidiasis might develop (40). People suffering from malnutrition, diabetes, or idiopathic hypoparathyroidism are also susceptible to candidiasis $(41,42,43)$.

It is not surprising, therefore, that man has tried to increase the susceptibility of mice to Candida albicans by pre-treating mice. There are several reasons that make an increased mortality rate in mice desirable:

(a) Increased death rates enable one to do chemotherapeutic studies in a shorter time period.

(b) Treated mice may be used as a diagnostic tool. Hopefully the treated mouse will show typical pathologic symptoms sooner than untreated mice.

(c) Mice are cheaper than other laboratory animals and also utilize less space.

Since some earlier work showed that certain surface-active agents increased the susceptibility of mice to bacteria, and because surface-active agents were much easier to manipulate than gastric mucin and roentgen 
radiation, an attempt was made to evaluate the action of certain non-ionic surface-active agents on the susceptibility of white Swiss mice to Candida albicans.

The effects of Mulsor 224, Pluronic L62, Plurafac B26 and Polyethylene G1ycol 400 Mono Laurate were determined on female Swiss mice. Also LD50's were ascertained for Candida albicans and for various Candida albicanssurface-active agent combinations when injected intraperitoneally into these animals.

other studies included heart blood cultures of infected mice, histological studies of mouse kidneys, and in vivo studies of the effects of surface-active agents on intraperitoneal leukocytes. A non-pathogen, Candida utilis, was also injected with surface-active agents to act as a system control.

The above experiments al lowed the author to suggest the mechanism of surface-active action. 


\section{MATERIALS}

Organisms

A strain of Candida albicans was secured from the Department of Microbiology stock culture collection and was maintained on Sabouraud dextrose agar slants at room temperature $\left(24^{\circ} \mathrm{C}\right)$. The organism was transferred monthly to insure viable cells for the experiments. The culture was checked periodically by the method of Martin to determine culture purity (44).

A strain of Candida utilis also was obtained from the departmental collection and was used in a series of experiments. This cuiture was maintained as outlined above.

Media

All cultures were maintained on Bacto-Sabouraud dextrose agar purchased from Difco Laboratories, Detrolt, Michigan. This medium contained 10 grams of neopeptone, 40 grams of dextrose, and 15 grams of agar per 11 ter. Surfactant-Sabouraud liquid media were also used for a series of experiments. Ninety-nine samples of Sabouraud liquid medium were autoclaved at 15 pounds pres- 
sure for 15 minutes. The following quantities of surfactants were added: $0.3 \mathrm{ml}$ of Polyethylene Glycol 400 Mono Laurate and $0.2 \mathrm{ml}$ of Mulsor 224.

Sabouraud Ilquid medium was used throughout the project to grow large numbers of Candida organisms. This medium consisted of 10 grams neopeptone and 20 grams dextrose per liter. One hundred $\mathrm{ml}$ samples of the broth were prepared in $500 \mathrm{ml}$ Erlenmeyer flasks and were sterilized by autoclaving for 15 minutes at $121^{\circ} \mathrm{C}$.

Other media were used to constantly identify our culture of Candida albicans. These included 1 per cent glucose, maltose, sucrose, and lactose broths with phenol red indicators, blood agar plates, and corn meal agar plates.

\section{Surface-Active Agents}

Four non-ionic surface-active agents were used: (a) Mulsor 224--composed of long chain fatty acid esters of polyethylene glycol (Synthetic Chemicals, Inc., Paterson, New Jersey), (b) Polyethylene Glycol 400 Mono Laurate--composed of a monoester of polyethylene glycol 400 and lauric acid (Glyco Products Co., Brooklyn, New York), (c) Pluronic L62--a condensate of ethylene oxide with a hydrophobic base formed by condensing propylene oxide with propylene 
glycol (Wyandotte Chemicals Corp., Wyandotte, Michigan), and (d) Plurafac B26--an oxyethylated stralght chain alcohol (Wyandotte Chemicals Corp., Wyandotte, Michigan).

All of the surface-active agents were 100 per cent concentrated.

Mice

Five-week old female Swiss mice were obtained periodically from Gopher State Caviary, St. Paul, Minnesota. These mice weighed between 20 and 24 grams. Female mice, which were used for preliminary experiments, were also obtained from the Biochemistry Animal Quarters at the University of North Dakota.

Needles and Syringes

Throughout the research, sterlle non-pyrogenic 2.5 mi disposable syringes and sterile, disposable 25 gauge needles served for the injection experiments (Becton, Dickinson and Company, Rutherford, New Jersey). Non-Pyrogenic Saline

Sterile, non-pyrogenic 0.9 per cent saline was used in several experiments. This was obtained from Baxter Laboratories, Inc., Morton Grove, Illinois. 


\section{METHODS}

\section{Effect of Surface-Active Agents}

Inftially, the effects of Polyethylene Glycol

400 Mono Laurate, Mulsor 224, Pluronic L62, and Plurafac B26 were determined on white Swiss mice. Surfactant concentrations of 0.2 per cent, 0.5 per cent, 0.75 per cent, 1.0 per cent, 2.0 per cent, and 20.0 per cent were prepared and $0.5 \mathrm{ml}$ portion of the solutions were injected intraperitoneally.

The solutions were prepared as follows: A 1.0 per cent concentration was prepared by adding $0.1 \mathrm{ml}$ of surfactant to $9.9 \mathrm{ml}$ of 0.85 per cent saline. Other solutions were prepared in an analogous manner.

The mice were observed dally to determine the lethality of the surfactants. Macroscopic observation of the peritoneal cavities followed. Characteristics of Candida albicans

A culture that had the following characteristics was considered to be Candida albicans: (a) no surface growth on Sabouraud acid broth, (b) typical, uniform, large, round, grayish colonies on blood agar streaked from Sabouraud broth and incubated for 10 days at $37^{\circ} \mathrm{C}$, 
(c) fermentation of glucose and maltose with acid and gas, formation of acid in sucrose, and no fermentation of lactose in 1.0 per cent carbohydrate broths incubated for 10 days at $37^{\circ} \mathrm{C}$, and (d). typical branching tree-like mycelium with chlamydospores in corn meal agar plates incubated for 10 days at: $37^{\circ} \mathrm{C}$.

Preparation of the Organisms

Four days before an experiment was scheduled an inoculum of Candida albicans was placed in a flask of Sabouraud liquid medium. The cells were allowed to grow at room temperature $\left(24^{\circ} \mathrm{C}\right)$ for 48 hours. The broth cultures were then placed in sterile tubes and centrifuged at $3000 \mathrm{rpm}$ for 15 minutes. The supernate was removed, and the organisms were resuspended in 0.85 per cent saline. These were centrifuged again and the saline was removed. A total of three saline washings was run (unless otherwise stated). The organisms were finally resuspended in 0.85 per cent saline.

Pour plate dilutions of the cell suspensions were made. Two days later the dilutions showing 30-30 colonfes per plate were counted on a Quebec counter. The number of organisms present per $\mathrm{ml}$ in the original suspension was thus determined.

The proper dilution of organisms was made for each experiment. Pour plates were once again prepared 
to determine if the proper dilution had been made. General Procedure

A $10 \mathrm{ml}$ surfactant-organism solution was usually prepared. Preliminary calculations showed the volume of organisms that would result in the desired number of organisms per $\mathrm{ml}$ when diluted up to $10 \mathrm{ml}$. The remalnder of the $10 \mathrm{ml}$ volume was composed of 0.85 per cent saline and surface-active agents.

Firstly, the desired amount of saline and surfactant was placed in a sterile vial; secondly, the necessary volume of cells was added to the mixture. (Preliminary work showed that if organisms were added to undlluted surfactants, death of many organisms resulted). A $1.0 \mathrm{ml}$ sample was removed for plate counts; portions of the remainder of the mixture were injected into white swiss mice. A separate $2.5 \mathrm{ml}$ syringe was used for each organism-surfactant combination, and also a new sterlle needle was used for each animal.

The caged mice ( $5 \mathrm{mice}$ per cage) were provided with laboratory chow and water dally. Upon the death of the mice (especially those mice that died within 48 hours after injection) the peritoneal cavity was observed macroscopically to determine if death was due to hemorrhage as 
a result of injection.

The mice were observed dally for a 30 day period, at which time all surviving mice were destroyed. Determination of LO50

The classical method of Reed and Muench was used to determine the LO50's (45). With this method it was assumed that an animal alive at a given dilution (efther of surfactant or Candida albicans, depending on the experiment) would have lived at a higher dilution; and conversely, an animal dead at a given difution would have died at a lower one. An example of the calculations follows:

\section{Total}

Dilution
Alive

Deadt
Alive
Per cent Dead* Mortality
$1: 2$

$1: 4$

$1: 8$

$1: 16$

$1: 32$

5
5

4

2

1

0
0

1

4

8

13
12

7

3

1

0
100

88

43

12

*30 days

FORMULA FOR CALCULATION PER CENT ENDPOINT:

$\frac{\% \text { dead above } 50 \%-50 \%}{\% \text { dead above } 50 \%-\% \text { dead below } 50 \%}$

= Proportional Distance 


$$
\frac{88 \%-50 \%}{88 \%-43 \%}=\frac{33}{45}=.73
$$

Logarithm of 4 (lower dilution)

.73 (proportional distance)

$x$ logarithm of 2 (dilution factor)

Sum (logarithm of endpoint)

The antilogarithm of 0.822 is 6.63 , therefore the LD50 dilution is $1: 6,63$.

LD50 of Varying Amounts of Surfactants Plus a Constant Amount of Candida albicans

Dllutions of 1.0 per cent, 0.75 per cent, 0.5 per cent, and 0.25 per cent of the four previously mentioned surfactants were prepared. These solutions also contained $4 \times 10^{7}$ organisms per $\mathrm{ml}$. One-half $\mathrm{ml}$ of each dilution of surfactant-Candida albicans mixture was injected intraperitoneally into each of $10 \mathrm{mice}$. Saline and Candida albicans controls were also included. The mice were observed for 30 days at which time the LD50's were determined.

LD50's of Candida albicans Combined With 1 Per Cent Surfactant Solutions

One per cent surfactant solutions containing varying numbers of Candida albicans were prepared as outlined 
above. Each mouse received $0.5 \mathrm{ml}$ of a surfactant-Candida albicans preparation intraperitoneally. A total of 10 mice for each surfactant-organism mixture was used. The mice were observed for a 30 day period, and the LD50's were calculated.

Experimental Trials of Non-pathogenic Candida utilis and Surfactants on Mice

The effects of 2 surfactant-Candida utilis combinations on mice were determined. One per cent solutions of Plurafac 826 containing $4 \times 10^{7}$ Candida utilis organisms per $\mathrm{mi}$ and Polyethylene Glycol 400 Mono Laurate containing $4 \times 10^{7}$ Candida utilis organisms per $\mathrm{ml}$ were prepared. One-half $\mathrm{ml}$ samples of each combination were injected intraperitoneally into white Swiss mice. The mice were checked for 30 days to determine if the solutions were infectious.

In vivo Leukocytic Response to a Candida albicans-Surfactant Combination

Candida albicans organisms were washed 3 times with 0.85 per cent saline as above, and then were washed 3 times with sterlle, non-pyrogenic saline (Baxter Laboratories Inc., Morton Grove, Illinois). Candida albicans solutions were placed in sterile bottles that had been washed in a Tryion Ultrasonic Cleaner (A.S. Aloe Co., Minneapolis, 
Minnesota) and then rinsed 3 times in distilled water, 3 times in double-distilled water, and 3 times in nonpyrogenfe saline.

The technique of Fruhman was modified for this study (46). Control mice received $0.5 \mathrm{ml}$ of sterile, non-pyrogenic 0.9 per cent saline intraperitoneally. Three other $0.5 \mathrm{ml}$ solutions were injected: (a) $2 \times 10^{7}$ Candida albicans, (b) $2 \times 107$ Candida albicans plus 1 per cent Plurafac B26, and (c) $2 \times 10^{7}$ Candida albicans plus 1 per cent Polyethylene Glycol 400 Mono Laurate. After 3 and 5 hours, mice were sacrificed and $0.5 \mathrm{ml}$ of heparinIzed 0.85 per cent saline was injected intraperitoneally. This was done because after 3 and 5 hours most of the original $0.5 \mathrm{ml}$ of saline was absorbed. The abdomen was massaged gently for 1 minute. An incision was made in the peritoneal cavity and the fluid was collected with a sterile syringe and needle. The volumes of the collected fluids were measured, and white blood cell counts were determined with a Neubauer hemocytometer. Differential counts were obtained after staining with Wright's solutions. Percentages and total numbers of Iymphocytes-monocytes, neutrophiles, and eosinophiles were thus obtained. 
Experimental Trials of Candida albicans and Candida albicansSurfactant Mixtures of Certain Mouse Tissues

Solutions of 1.0 per cent Plurafac B26 Candida albicans $\left(4 \times 10^{7}\right.$ organisms $\left./ \mathrm{mi}\right)$ and of Candida albicans ( $4 \times 10^{7}$ organisms $/ \mathrm{ml}$ ) were injected into mice. After death of the animals or after 24 hours (whichever came first), the kidneys and the pancreas were removed and placed in formalin. No other tissues were studied as others had reported that the before-mentioned organs were the foci of infection (47). Periodic acid - Schiff and methenamine silver stains of the tissues were prepared by the UND Pathology Laboratory. Micro-photographs were made of representative tissue sections.

An effort was also made to isolate Candida albicans from the blood of infected animals. Blood was removed from the mice by snipping the tail. Samples were obtained at $0,2,4,8$ and 24 hours from mice injected with $2 \times 107$ Candida albicans. Heart blood cultures were prepared from mice that died within 24 hours or from the mice sacrificed at the end of 24 hours.

Tail-blood cultures were al so prepared from mice infected with $6.7 \times 10^{8}$ Candida albicans. At the time of death of the mice (usually within 24 hours), heart 
blood cultures were prepared, and the kidneys and pancreas were removed for tissue studies as before.

Experimental Trials of Candida albicans Grown in Surfactant Culture Media Mixtures on White Swiss Mice

Marwin reported that Candida albicans organisms grew faster in media containing 0.3 per cent polyethylene Gl ycol 400 Mono Laurate and 0.2 per cent Mulsor 224 than in control media (48); therefore, attempts to determine if cells grown in the before-mentioned media would be more pathogenic for white Swiss mice than Candida albicans alone were undertaken. Candida albicans organisms were grown in $99 \mathrm{ml}$ samples of Sabouraud liquid medfum containing the desired surfactant. After 48 hours the cells were harvested and washed 3 times with 0.85 per cent saline. The cells were resuspended in 0.85 per cent saline, and plate counts were made.

Varlous dilutions of the surfactant-grown organisms were injected into mice to determine the LD50's. The LD50 of Candida albicans grown without surfactants was also included in the experiments. 


\section{RESULTS}

Examination of Table 1 shows that non-ionic surface-active agents are not uniformly lethal for female white Swiss mice. One observes that the level of toxicity for Polyethylene Glycol 400 Mono Laurate and Plurafac $B 26$ is between 1.0 and 2.0 per cent, with Plurafac 826 being the more toxic of the two surfactants. The toxic levels of Muisor 224 and Pluronic L62 were not determined. Autopsied animals revealed no pathologic abnormalfties; however, a large amount of fluid gathered in the peritoneal cavity following the intraperitoneal injections of the surfactants. To insure that deaths in later experiments would not be due to surfactant action, concentrations of 1.0 per cent or less were used in the remaining experiments.

The Candida albicans culture was checked periodically by methods described above. Invariably, the culture produced acid and gas from glucose and maltose, produced acid from sucrose, and falled to ferment lactose. The culture also falled to grow on the surface of Sabouraud liquid media, formed grey colonies on blood agar, and formed chlamydospores in corn meal agar plates. 
Table 1. - Lethality of various concentrations of surfactants injected intraperitoneally in $0.5 \mathrm{ml}$ volumes

\begin{tabular}{|c|c|c|c|}
\hline Surfactant & & Deaths Per 10 Mice & \\
\hline $\begin{array}{l}\text { Concentration } \\
\text { Per cent }\end{array}$ & $\begin{array}{l}\text { Polyethylene } \\
\text { Glycol } 400 \\
\text { Mono Laurate }\end{array}$ & Mulsor 224 Pluronic L62 & Plurafac B 26 \\
\hline
\end{tabular}

\begin{tabular}{lllll}
\hline $0.2 \%$ & 0 & 0 & 0 & 0 \\
$1.0 \%$ & 0 & 0 & 0 & 0 \\
$2.0 \%$ & $3^{x}$ & 0 & 0 & $7^{y}$ \\
\hline
\end{tabular}

Observation period - 30 days

Died within 2 days

$y_{\text {Died }}$ within 3 days 
The pathogenfeity of the culture, which remained stable throughout the project, was checked by determining LD50's. The results of Tables 2 and 3 show that the LD50 is near $10^{8}$ organisms. Calculation from these data yielded LD50's of $7 \times 10^{7}$ for Table 2 and $8.4 \times 10^{7}$ for Table 3. A combination of the data gave an LO50 of Candida albicans of $7.7 \times 10^{7}$ (Table 16).

A study of Tables $4-9$ and $10-15$ shows that surfactants increase the susceptibility of mice to Candida albicans. Tables $4-9$ condense an attempt to determine the effect of various amounts of each surfactant with a constant amount of Candida albicans. They show that apparently Plurafac $B 26$ is the most effective susceptibilityenhancing agent and Polyethylene Glycol 400 Mono Laurate the least effective. Mulsor 224 and Pluronic L62 are intermediate in effect. These data are presented as the LD50 of each surfactant (Table 17). The percentage of surfactant plus $2 \times 10^{7}$ Candida albicans that kills 50 per cent of white Swiss mice are 0.33 per cent Plurafac B26, 0.84 per cent Polyethylene Glycol 400 Mono Laurate, 0.64 per cent Mulsor 224 and 0.61 per cent Pluronic $L 62$. The attempts to characterize the actions of the surfactants are summarized in Tables 10-15. Here the 
Table 2. - Fatalities of female Swiss mice injected with varying amounts of Candida albicans - Series I

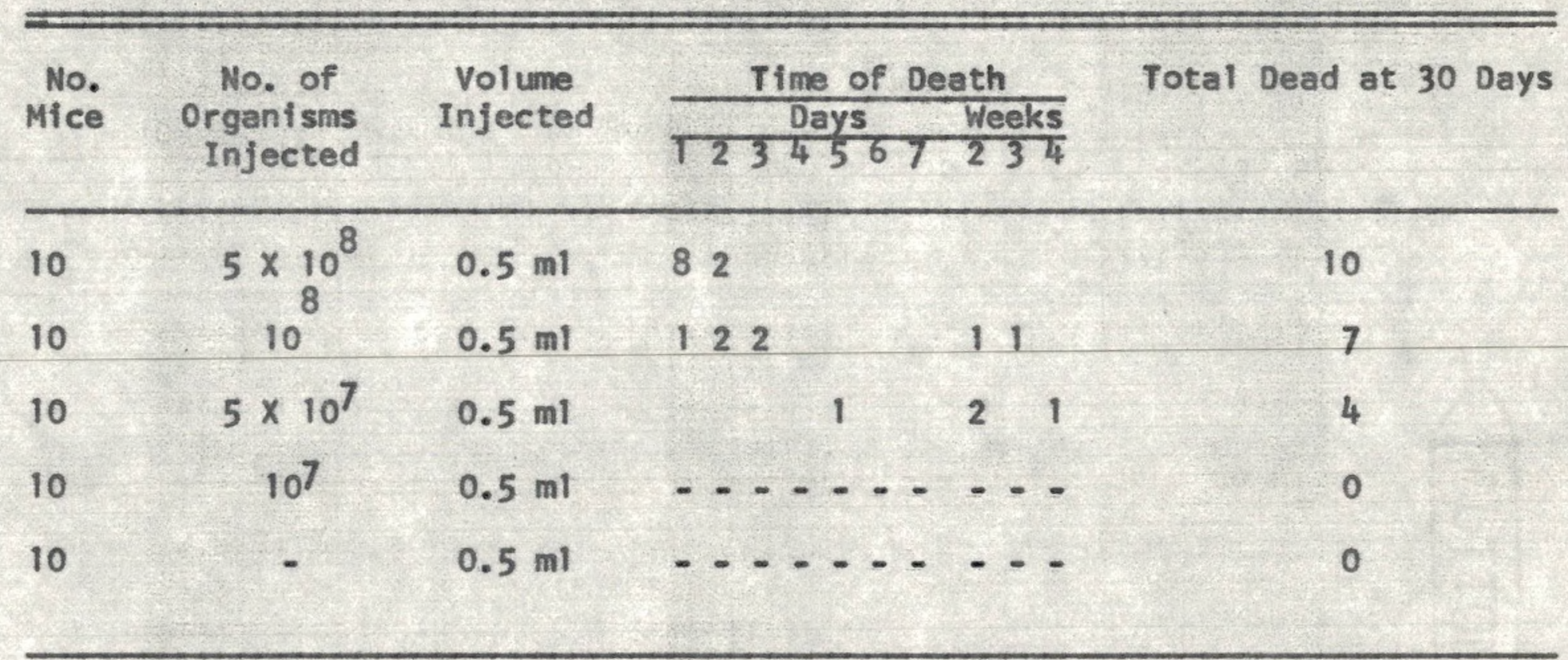


Table 3. - Fatalities of female Swiss mice injected with varying amounts of Candida albicans - Series II

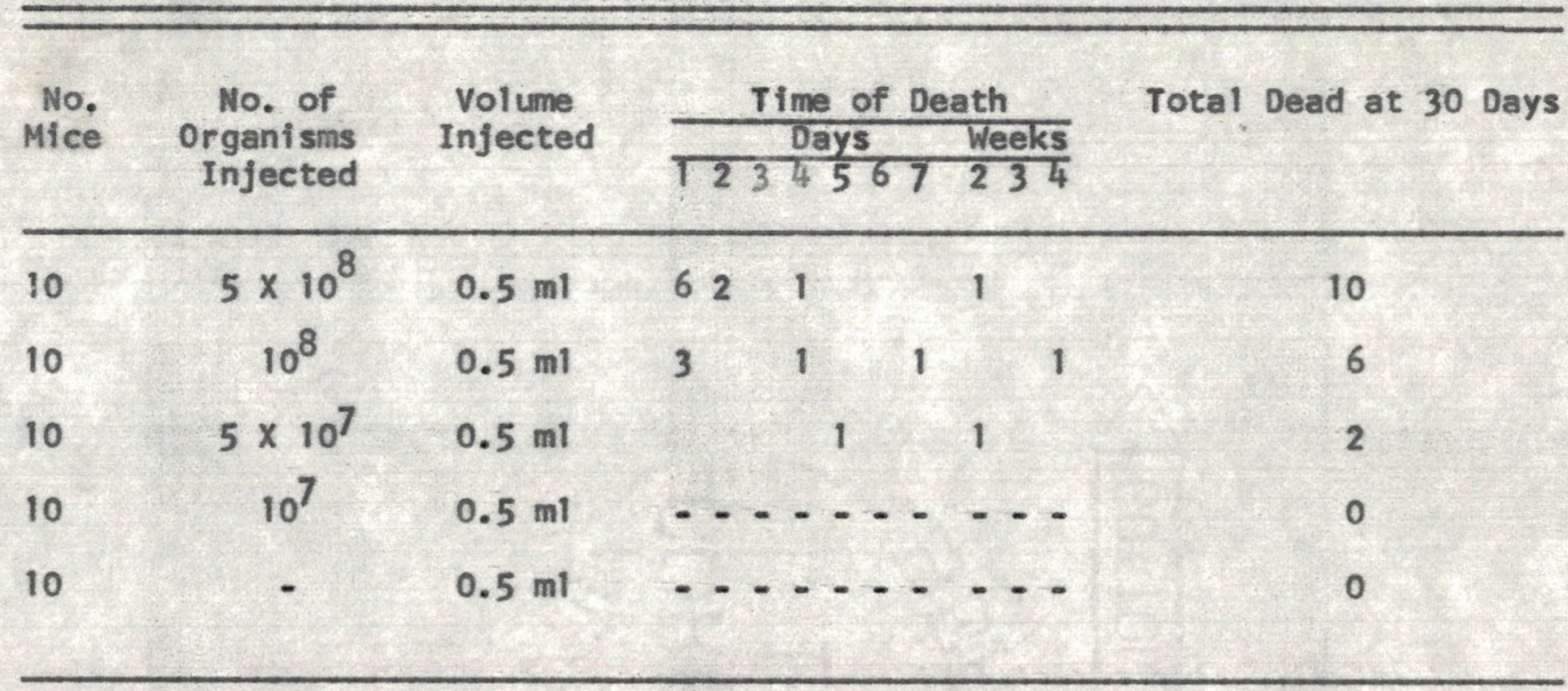


Table 4. - Fatalities of female Swiss mice injected with Candida albicans and varying percentages of Plurafac B26 - Series I

\begin{tabular}{|c|c|c|c|c|c|c|c|c|c|}
\hline \multirow[b]{2}{*}{ Pluraf } & \multirow[b]{2}{*}{ fac 126} & \multirow{2}{*}{$\begin{array}{l}\text { No. } \\
\text { Mice }\end{array}$} & \multirow{2}{*}{$\begin{array}{l}\text { No. of } \\
\text { Organisms } \\
\text { Injected }\end{array}$} & \multirow{2}{*}{$\begin{array}{l}\text { Volume } \\
\text { Injected }\end{array}$} & \multicolumn{4}{|c|}{ Time of Death } & \multirow{2}{*}{$\begin{array}{l}\text { Total } \\
\text { at } 30\end{array}$} \\
\hline & & & & & & & $\frac{\text { Days }}{4567}$ & $\frac{\text { Weeks }}{234}$ & \\
\hline & $1.0 \%$ & 10 & $2 \times 10^{7}$ & $0.5 \mathrm{mi}$ & 10 & & & & 10 \\
\hline & $0.75 \%$ & 10 & $2 \times 10^{7}$ & $0.5 \mathrm{ml}$ & $7:$ & 2 & 1 & & 10 \\
\hline & $0.50 \%$ & 10 & $2 \times 10^{7}$ & $0.5 \mathrm{ml}$ & 63 & 3 & & & 9 \\
\hline & $0.25 \%$ & 10 & $2 \times 10^{7}$ & $0.5 \mathrm{ml}$ & 13 & & & & 4 \\
\hline & $1.0 \%$ & 10 & $\cdots$ & $0.5 \mathrm{ml}$ & - & - & $\ldots$ & $\ldots$ & 0 \\
\hline Saline & e Control & 10 & -. & $0.5 \mathrm{ml}$ & - & - - & $\ldots$ & -.. & 0 \\
\hline
\end{tabular}


Table 5. - Fatalities of female Swiss mice injected with Candida albicans and varying percentages of Plurafac B26 - Series II

\begin{tabular}{|c|c|c|c|c|c|c|c|}
\hline Plurafa & ac 826 & $\begin{array}{l}\text { No. } \\
\text { Mice }\end{array}$ & $\begin{array}{l}\text { No. of } \\
\text { Organisms } \\
\text { Injected }\end{array}$ & $\begin{array}{l}\text { Volume } \\
\text { Injected }\end{array}$ & $\frac{T}{T 23}$ & $\begin{array}{l}\text { Ime of Death } \\
\text { Days }\end{array}$ & $\begin{array}{l}\text { Total Dead } \\
\text { at } 30 \text { Days }\end{array}$ \\
\hline & $1.0 \%$ & 10 & $2 \times 10^{7}$ & $0.5 \mathrm{ml}$ & 10 & & 10 \\
\hline & $0.75 \%$ & 10 & $2 \times 10^{7}$ & $0.5 \mathrm{ml}$ & 1 & 1 & 10 \\
\hline & $0.50 \%$ & 10 & $2 \times 10^{7}$ & $0.5 \mathrm{ml}$ & 51 & 1 & 8 \\
\hline & $0.25 \%$ & 10 & $2 \times 10^{7}$ & $0.5 \mathrm{ml}$ & 31 & & 4 \\
\hline & $1.0 \%$ & 10 & $\cdots$ & $0.5 \mathrm{ml}$ & -- & $--\cdot$ & 0 \\
\hline Saline & Control & 10 & - & $0.5 \mathrm{ml}$ & -- & $-\cdots-\ldots$ & 0 \\
\hline
\end{tabular}


Table 6. - Fatalities of Eemale Swiss mice injected with Candida albicans and varying percentages of Folyethylene Glycol 400 Mono Laurate - Series I

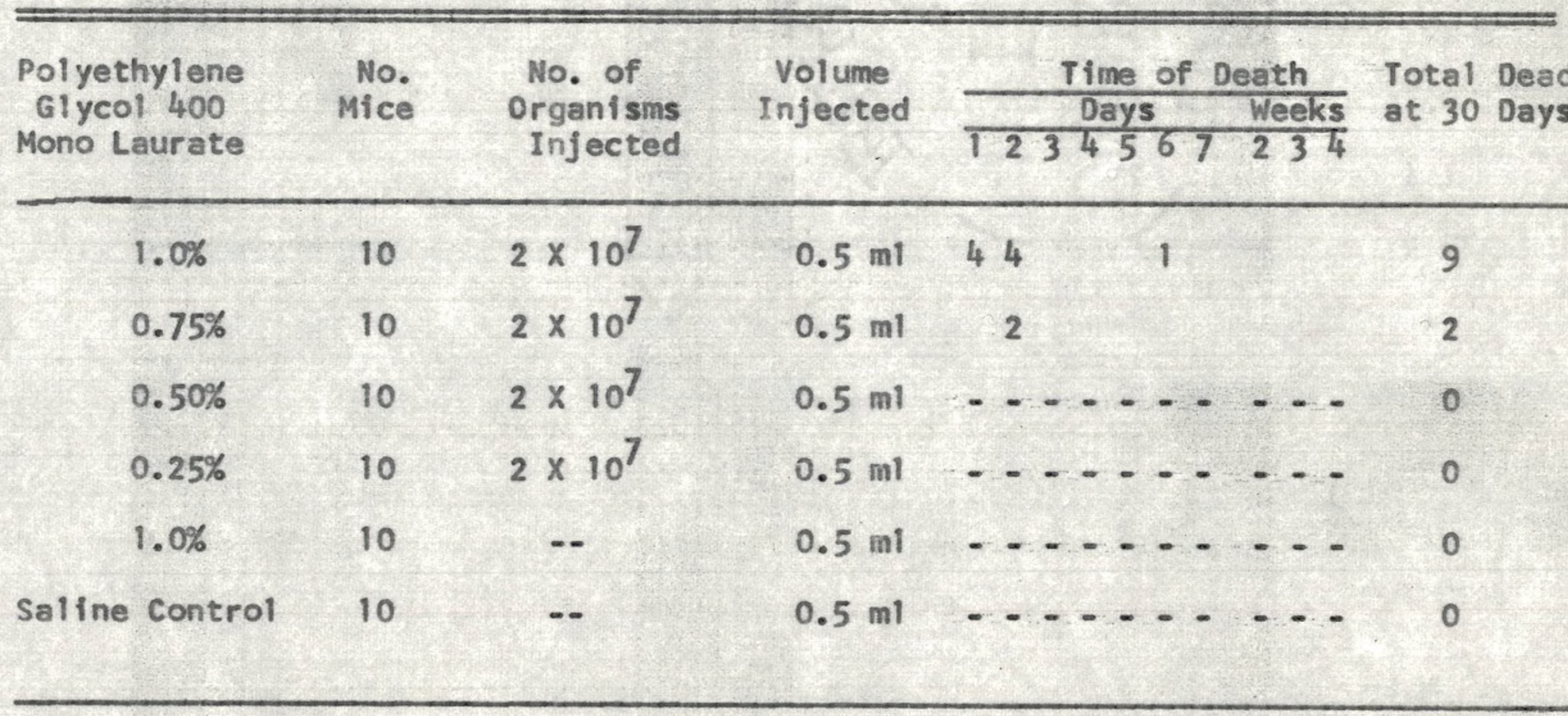


Table 7. - Fatalities of female Swiss mice injected with Candida albicans and varying percentages of Polyethylene Glycol 400 Mono Laurate - series II

\begin{tabular}{|c|c|c|c|c|c|c|c|c|c|}
\hline $\begin{array}{l}\text { Polyethylene } \\
\text { Glycol } 400 \\
\text { Mono Laurate }\end{array}$ & $\begin{array}{l}\text { No. } \\
\text { Mice }\end{array}$ & $\begin{array}{l}\text { No. of } \\
\text { Organisms } \\
\text { Injected }\end{array}$ & $\begin{array}{l}\text { Volume } \\
\text { Injected }\end{array}$ & \multicolumn{4}{|c|}{ Time of Death } & \multicolumn{2}{|c|}{$\begin{array}{l}\text { Tota } 1 \text { Dead } \\
\text { at } 30 \text { Days }\end{array}$} \\
\hline $1.0 \%$ & 10 & $2 \times 107$ & $0.5 \mathrm{mi}$ & 81 & 1 & & & 10 & \\
\hline $0.75 \%$ & 10 & $2 \times 10^{7}$ & $0.5 \mathrm{ml}$ & 11 & 1 & & & 3 & \\
\hline $0.50 \%$ & 10 & $2 \times 10^{7}$ & $0.5 \mathrm{ml}$ & - - & $---\cdot=$ & . & - & 0 & \\
\hline $0.25 \%$ & 10 & $2 \times 10^{7}$ & $0.5 \mathrm{ml}$ & - - & - - - - & - & - & 0 & \\
\hline $1.0 \%$ & 10 & -. & $0.5 \mathrm{ml}$ & - - & 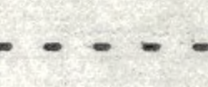 & - & - & 0 & \\
\hline Saline Control & 10 & -. & $0.5 \mathrm{ml}$ & - & -.- & 6 & - & 0 & \\
\hline
\end{tabular}


Table 8. - Fatalities of female Swiss mice injected with Candida albicans and varying percentages of Mulsor 224

\begin{tabular}{|c|c|c|c|c|c|c|c|c|c|}
\hline Mulsor 224 & $\begin{array}{l}\text { No. } \\
\text { Mice }\end{array}$ & $\begin{array}{l}\text { No. of } \\
\text { Organisms } \\
\text { Injected }\end{array}$ & $\begin{array}{l}\text { Volume } \\
\text { Injected }\end{array}$ & & $\frac{\text { Time }}{2345}$ & $\frac{\text { of } 0}{67}$ & $\frac{\text { Death }}{\frac{\text { Weeks }}{7234}}$ & $\begin{array}{l}\text { Total } \\
\text { at } 30\end{array}$ & $\begin{array}{l}\text { Dead } \\
\text { Days }\end{array}$ \\
\hline $1.0 \%$ & 10 & $2 \times 10^{7}$ & $0.5 \mathrm{ml}$ & 61 & & 1 & 1 & 9 & \\
\hline $0.75 \%$ & 10 & $2 \times 10^{7}$ & $0.5 \mathrm{ml}$ & & 8 & & & 8 & \\
\hline $0.50 \%$ & 10 & $2 \times 10^{7}$ & $0.5 \mathrm{ml}$ & & 1 & & 1 & 2 & \\
\hline $0.25 \%$ & 10 & $2 \times 10^{7}$ & $0.5 \mathrm{mi}$ & - &.-- & - & $-\ldots$ & 0 & \\
\hline $1.0 \%$ & 10 & -. & $0.5 \mathrm{mi}$ & & $--\cdot-$ & - & $-\quad-$ & 0 & \\
\hline Saline control & 10 & $\ldots$ & $0.5 \mathrm{ml}$ & - & 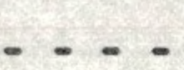 & - & $-\quad--$ & 0 & \\
\hline
\end{tabular}


Table 9. - Fatallties of female Swiss mice injected with Candida albicans and varying percentages of Pluronic $\mathrm{L} 62$

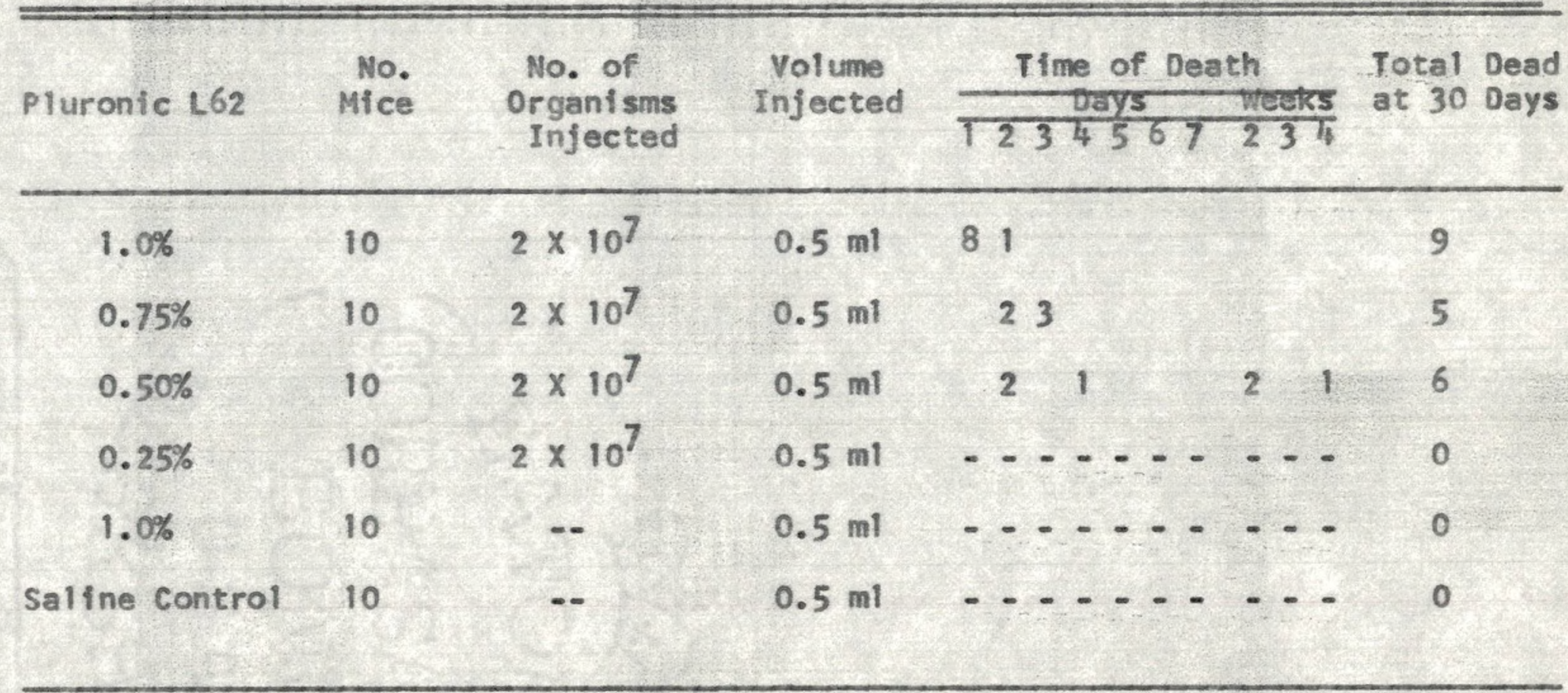


Table 10. - Fatalities of female Swiss mice injected with 1.0 per cent Plurafac B26 and varying numbers of Candida albicans - Serfes I

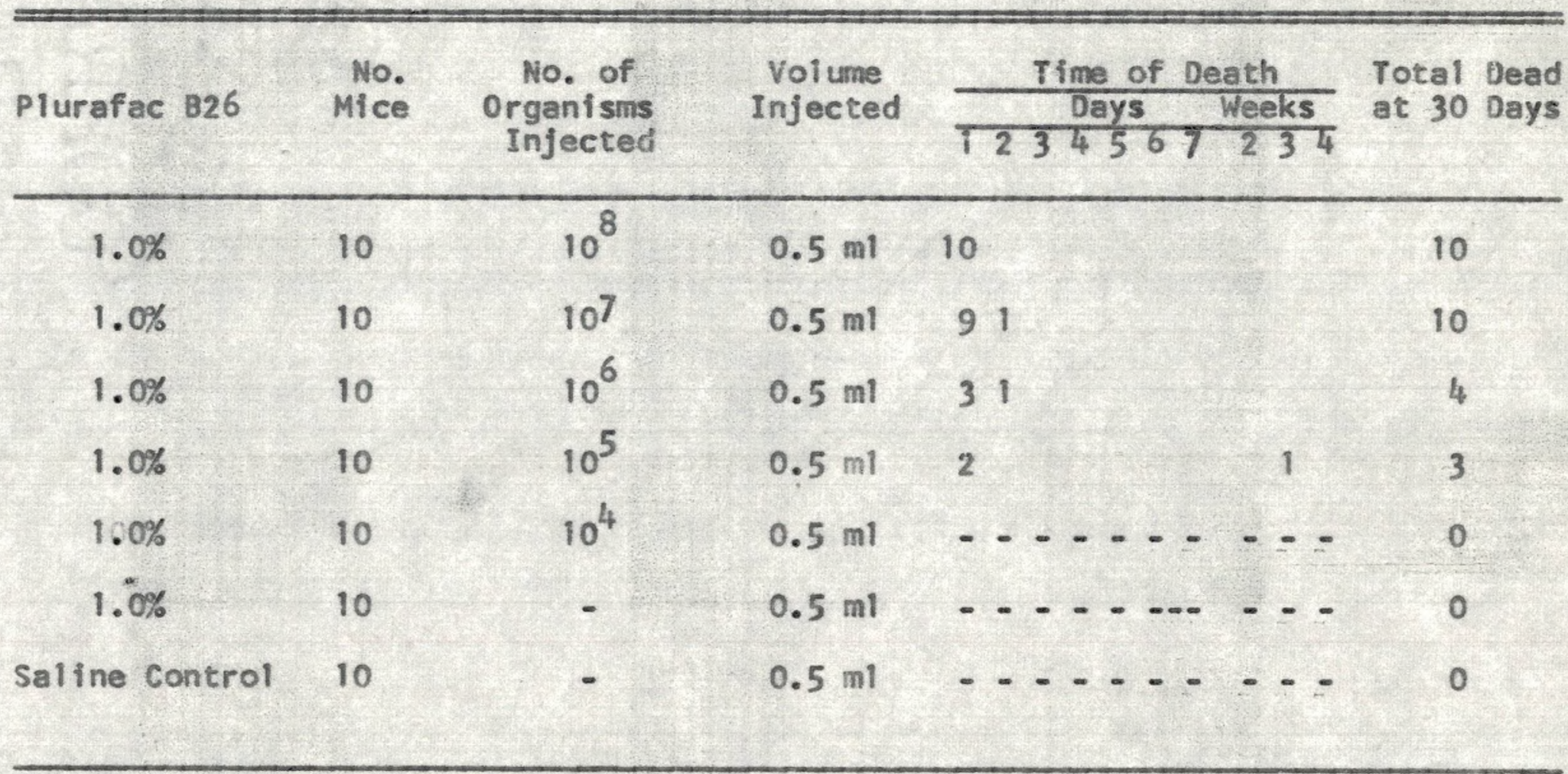


Table 11. - Fatalities of female Swiss mice injected with 1.0 per cent Plurafac 826 and varying numbers of Candida albicans - Series II

\begin{tabular}{ccccc}
\hline Plurafac B26 & No. & $\begin{array}{c}\text { No. of } \\
\text { Organisms } \\
\text { Injected }\end{array}$ & $\begin{array}{c}\text { Volume } \\
\text { Injected }\end{array}$
\end{tabular}

\begin{tabular}{|c|c|c|c|c|c|c|c|}
\hline $1.0 \%$ & 10 & $10^{8}$ & $0.5 \mathrm{ml}$ & 10 & & & 10 \\
\hline $1.0 \%$ & 10 & $10^{7}$ & $0.5 \mathrm{ml}$ & 10 & & & 10 \\
\hline $1.0 \%$ & 10 & $10^{6}$ & $0.5 \mathrm{ml}$ & 2 & & & 2 \\
\hline $1.0 \%$ & 10 & $10^{5}$ & $0.5 \mathrm{mil}$ & 2 & 11 & 1 & 4 \\
\hline $1.0 \%$ & 10 & $10^{5}$ & $0.5 \mathrm{ml}$ & $-\cdots$ & - - & $-\quad-\cdot$ & 0 \\
\hline $1.0 \%$ & 10 & $10^{4}$ & $0.5 \mathrm{ml}$ & $-\ldots$ & -- &.$--\cdot$ & 0 \\
\hline $1.0 \%$ & 10 & - & $0.5 \mathrm{ml}$ & --- & $\ldots$ & $-\ldots$ & 0 \\
\hline Saline Control & 10 & - & $0.5 \mathrm{ml}$ & $-\cdots$ & $\ldots$ & $-\ldots$ & 0 \\
\hline
\end{tabular}


Table 12. - Fatalities of female Swiss mice injected with 1.0 per cent Polyethylene Glycol 400 Mono Laurate and varying numbers

of Candida albicans - Series I

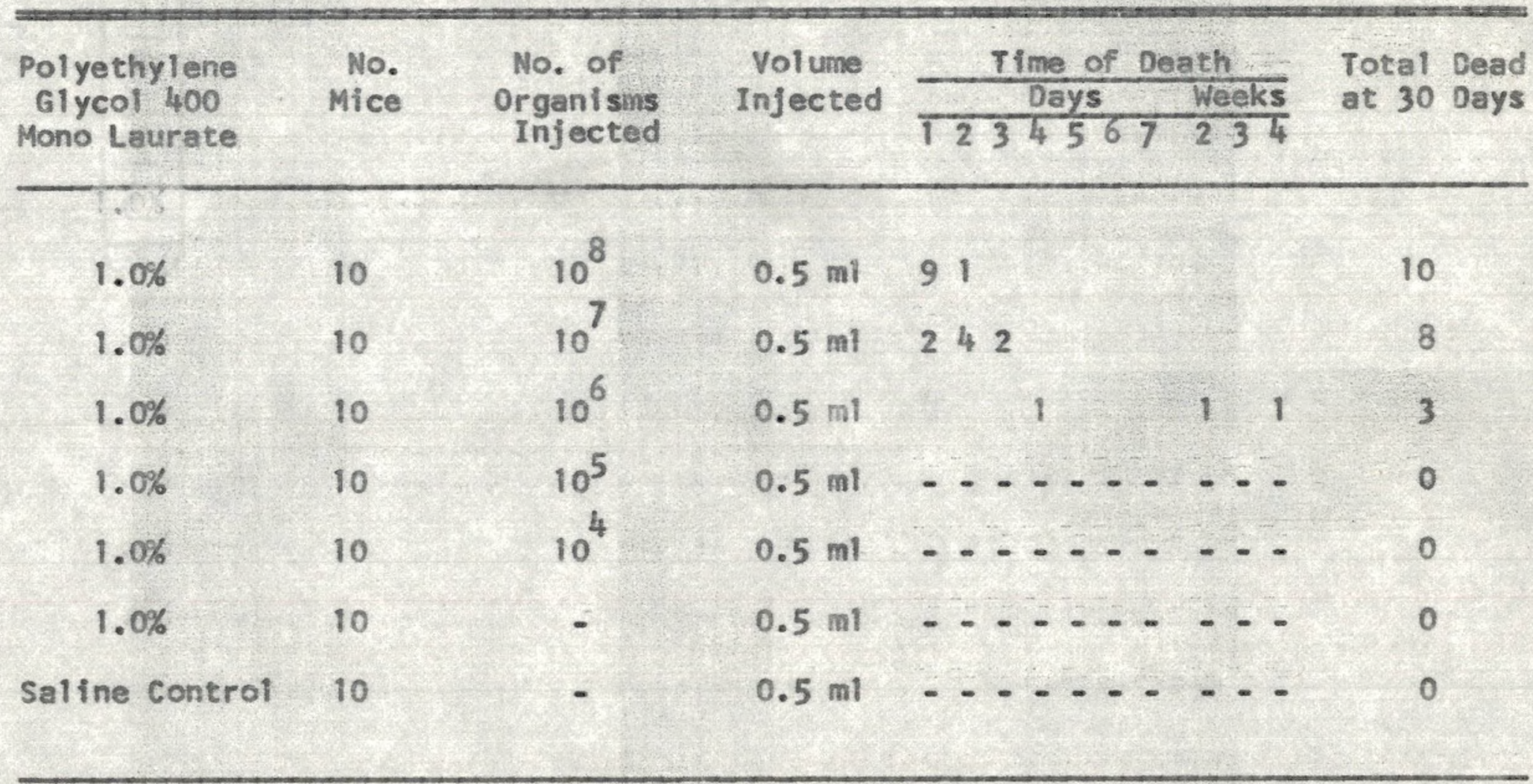


Table 13. - Fatalities of female Swiss mice injected with 1.0 per cent Polyethylene Glycol 400 Mono Laurate and varying numbers of Candida albicans - Series II

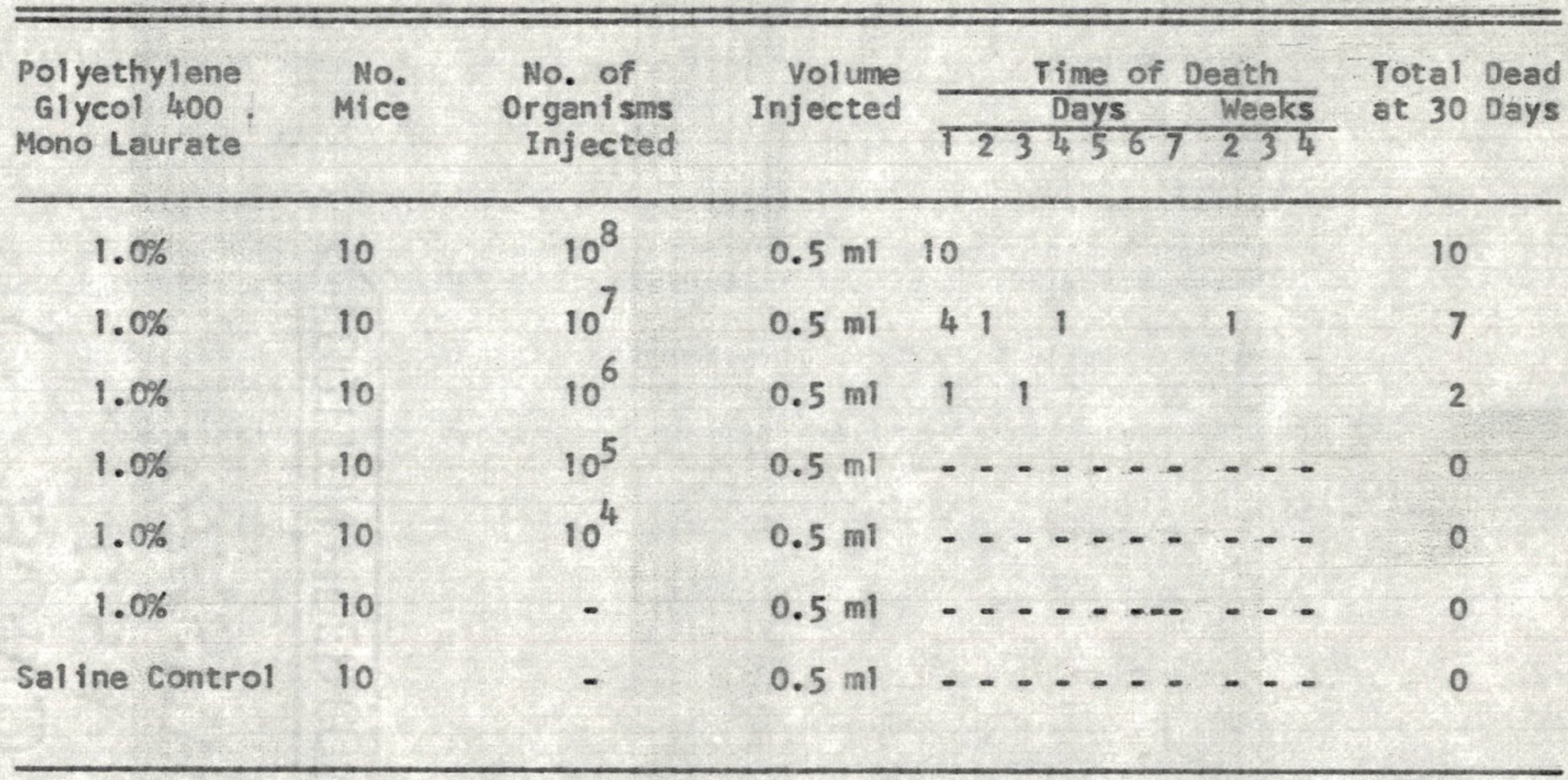


Table 14. - Fatalities of female Swiss mice injected with 1.0 per cent Pluronic $\mathrm{L} 62$ and varying numbers of Candida albicans

\begin{tabular}{|c|c|c|c|c|c|c|}
\hline Pluronic L52 & $\begin{array}{l}\text { No. } \\
\text { Mice }\end{array}$ & $\begin{array}{l}\text { No. of } \\
\text { Organisms } \\
\text { Injected }\end{array}$ & $\begin{array}{l}\text { Vol ume } \\
\text { Injected }\end{array}$ & $\overline{T 2}$ & $\frac{\text { Time of Week }}{\text { Days Weeks }}$ & $\begin{array}{l}\text { Total Dead } \\
\text { at } 30 \text { Days }\end{array}$ \\
\hline $1.0 \%$ & 10 & $10^{8}$ & $0.5 \mathrm{mi}$ & 73 & & 10 \\
\hline $1.0 \%$ & 10 & $10^{7}$ & $0.5 \mathrm{mi}$ & 19 & & 10 \\
\hline $1.0 \%$ & 10 & $10^{6}$ & $0.5 \mathrm{ml}$ & 1 & & 1 \\
\hline $1.0 \%$ & 10 & $10^{5}$ & $0.5 \mathrm{ml}$ & - & $\ldots-\cdots,-\cdots$ & 0 \\
\hline $1.0 \%$ & 10 & $10^{4}$ & $0.5 \mathrm{ml}$ & - & 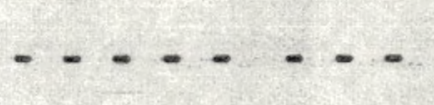 & 0 \\
\hline $1.0 \%$ & 10 & - & $0.5 \mathrm{mi}$ & - & $-\infty-\ldots+-\ldots$ & 0 \\
\hline Saline Control & 10 & - & $0.5 \mathrm{ml}$ & - - & $-\cdots-\cdots+-$ & 0 \\
\hline
\end{tabular}


Table 15. - Fatalities of female Swiss mice injected with 1.0 per cent Mulsor 224 and varying numbers of Candida albicans

\begin{tabular}{|c|c|c|c|c|c|c|c|}
\hline Mulsor 224 & $\begin{array}{l}\text { No. } \\
\text { Mice }\end{array}$ & $\begin{array}{l}\text { No. of } \\
\text { Organisms } \\
\text { Injected }\end{array}$ & $\begin{array}{l}\text { Vol ume } \\
\text { Injected }\end{array}$ & & $\frac{\text { Time of Death }}{\frac{\text { Days }}{234567} \text { Weeks }}$ & $\begin{array}{l}\text { Total } \\
\text { at } 30\end{array}$ & $\begin{array}{l}\text { Dead } \\
\text { Days }\end{array}$ \\
\hline $1.0 \%$ & 10 & $10^{8}$ & $0.5 \mathrm{ml}$ & 46 & & 10 & \\
\hline $1.0 \%$ & 10 & $10^{7}$ & $0.5 \mathrm{mi}$ & & 82 & 10 & \\
\hline $1.0 \%$ & 10 & $10^{\circ}$ & $0.5 \mathrm{ml}$ & 11 & & 2 & \\
\hline $1.0 \%$ & 10 & $10^{5}$ & $0.5 \mathrm{ml}$ & - & $----\cdots-\cdots$ & 0 & \\
\hline $1.0 \%$ & 10 & $10^{4}$ & $0.5 \mathrm{ml}$ & - & $---\cdots+-\cdots$ & 0 & \\
\hline $1.0 \%$ & 10 & - & $0.5 \mathrm{ml}$ & $\cdots$ & $\cdots+\cdots+\cdots$ & 0 & \\
\hline Saline Control & 10 & - & $0.5 \mathrm{mi}$ & $-\cdots$ & $\cdots-\cdots-\cdots-$ & 0 & \\
\hline
\end{tabular}


Table 16. - Summary of Tables 2, 3, and $10 \ldots 15$. LD50's of 1.0 per cent surfactants combined with Candida albicans

dilutions of $10^{4}, 10^{5}, 10^{6}, 10^{7}$, and $10^{8}$

\begin{tabular}{|c|c|c|}
\hline Mixture & No. Mice/Dilution & $\begin{array}{l}\text { LD50 } \\
\text { (No. of organisms) }\end{array}$ \\
\hline C. albicans & 20 & $7.7 \times 10^{7}$ \\
\hline $\begin{array}{c}\text { C. } \frac{\text { albicanst }}{\text { T. } \% \text { Plurafac }} \\
\text { B26 }\end{array}$ & 20 & $8.8 \times 10^{5}$ \\
\hline 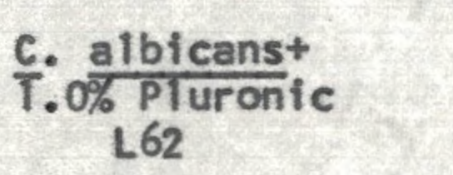 & 10 & $2.8 \times 10^{6}$ \\
\hline C. $\frac{\text { albicans }}{\text { T. }}+\frac{}{\text { Mulsor }} 224$ & 10 & $2.4 \times 10^{6}$ \\
\hline $\begin{array}{l}\text { C. albicans+ } \\
\text { T.0\% Poly. Glycol } \\
400 \text { Mono Laurate }\end{array}$ & 20 & $3.2 \times 10^{6}$ \\
\hline
\end{tabular}


Table 17. - Summary of Tables 4 - 9. L050's of $2 \times 10^{7}$ Candida albicans combined with surfactant dilutions of 0.25 per cent, 0.5 per cent, 0.75 per cent, and 1.0 per cent

\begin{tabular}{|c|c|c|}
\hline Mixture & No. Mice/ollution & $\begin{array}{c}\text { LO50 } \\
\text { (Surfactant concentration) }\end{array}$ \\
\hline $\begin{array}{l}2 \times 10^{7} \text { C. albicans } \\
+ \text { Plurafac } \\
\text { B26 }\end{array}$ & 20 & $0.33 \%$ \\
\hline $\begin{array}{l}2 \times 10^{7} \text { c. albicans } \\
+ \text { Poly. Giycol }\end{array}$ & 20 & $0.84 \%$ \\
\hline $\begin{array}{l}2 \times 10^{7} \mathrm{C} \text {. albicans } \\
+ \text { Pluronic } \frac{162}{L 2}\end{array}$ & 10 & $0.61 \%$ \\
\hline $\begin{array}{l}2 \times 10^{7} \text { c. albicans } \\
+ \text { Mulsor } 224\end{array}$ & 10 & $0.64 \%$ \\
\hline
\end{tabular}


percentage of surfactant was a constant 1.0 per cent. From the LD50 data of Table 16, we again see that surfactants increase mouse susceptibility to candida Hbieans. One observes that all of the surfactants decrease the LD50 by at least a factor of 20 . There also appears to be a lethalfty enhancing variation among the surfactants but the contrast is not as definite as the percentages of surfactants.

One can also observe a trend in the death rates by perusing Tables $2-15$. Overwhelming numbers of Candida albicans alone killed most of the mice within 3 days, but lower numbers of organisms produced a more chronic infection and deaths were distributed over a four week period (Tables 2, 3 ).

Analogous results were obtained when surfactants were added. The majority of mice that died expired within 3 days after injection, but at lower concentrations of surfactants or Candida albicans. Deaths were scattered over the initially stated observation period (Tables 4-15). Often mice injected with $5 \times 10^{7}$ and $10^{8}$ Candida albicans that survived the 30 day test period were emaciated at the completion of the experiment. Contrasted to this, mice surviving the surfactant-Candida albicans 
experiments appeared to be in fine health.

Usually the animals injected with 1.0 per cent surfactants or surfactant-Candida albicans were very inactive after injection, and they remained so for 12-18 hours. Mice injected with less than 1.0 per cent surfactants remained normally active.

Another experiment was conducted to determine if pathogenic properties of Candida albicans were necessary to get fatalities in the mice. Therefore, mixtures of 1.0 per cent surfactants and Candida utilis $\left(4 \times 10^{7}\right.$ organisms/ mi) were injected intraperitoneally into female white Swiss mice. These mice uniformly survived these mixtures.

To determine if Candida albicans grown in surfactant-Sabouraud media were more pathogenic, another experiment was run. The results are reported in Tables 18 and 19. The LD50's of cells grown in Mulsor 224 $\left(5.1 \times 10^{7}\right)$ and of cells grown in Polyethylene Giycol 400 Mono Laurate $(5.6 \times 107)$ are quite similar to those of Candida albicans alone (Table 16).

Total leukocyte counts are presented in Tables 20 and 21. Perhaps the most notable feature of these tables is the number of leukocytes present when $2 \times 10^{7}$ Candida organisms suspended in Plurafac 826 are injected. 
Table 18. - Fatalities of female Swiss mice injected with varying numbers of Candida albicans grown in Mulsor 224 Sabouraud Tiquid medium

\begin{tabular}{|c|c|c|c|c|c|}
\hline $\begin{array}{l}\text { No. } \\
\text { Mice }\end{array}$ & $\begin{array}{l}\text { No. of } \\
\text { Organisms } \\
\text { Injected }\end{array}$ & $\begin{array}{l}\text { Volume } \\
\text { Injected }\end{array}$ & $\frac{\text { Time of De }}{\text { Days }}$ & $\frac{\frac{\text { eath }}{\text { weeks }}}{234}$ & $\begin{array}{l}\text { Total Dead } \\
\text { at } 30 \text { Days }\end{array}$ \\
\hline 10 & $10^{8}$ & $0.5 \mathrm{ml}$ & 2112 & 1 & 7 \\
\hline 10 & $10^{7}$ & $0.5 \mathrm{ml}$ & $---=--$ & --- & 0 \\
\hline 10 & $10^{6}$ & $0.5 \mathrm{ml}$ & $-\ldots-\ldots$ & $--\cdot$ & 0 \\
\hline 10 & $10^{5}$ & $0.5 \mathrm{ml}$ & $-\infty---$ & $-=$ & 0 \\
\hline 10 & $10^{4}$ & $0.5 \mathrm{ml}$ & $\ldots-\cdots$ & -- & 0 \\
\hline 10 & - & $0.5 \mathrm{ml}$ & $----\cdot-$ & $-\cdots$ & 0 \\
\hline
\end{tabular}


Table 19. - Fatalities of female Swiss mice injected with varying numbers of Candida albicans grown in Polyethylene Glycol 400

Mono Laurate - Sabouraud Ifquid medium

\begin{tabular}{|c|c|c|c|c|c|}
\hline $\begin{array}{l}\text { No. } \\
\text { Mice }\end{array}$ & $\begin{array}{l}\text { No. of } \\
\text { Organisms } \\
\text { Injected }\end{array}$ & $\begin{array}{l}\text { Volume } \\
\text { Injected }\end{array}$ & $\frac{\text { Time of Dea }}{1234567}$ & $\frac{\frac{\text { ath }}{\text { Weeks }}}{234}$ & $\begin{array}{l}\text { Total Dead } \\
\text { at } 30 \text { Days }\end{array}$ \\
\hline 10 & $10^{8}$ & $0.5 \mathrm{mi}$ & 12 & 11 & 6 \\
\hline 10 & $10^{7}$ & $0.5 \mathrm{mi}$ & & 1 & 1 \\
\hline 10 & $10^{6}$ & $0.5 \mathrm{ml}$ & $-\ldots-\ldots$ & $\ldots$ & 0 \\
\hline 10 & $10^{5}$ & $0.5 \mathrm{ml}$ & $-\infty-\cdots$ & -- & 0 \\
\hline 10 & $10^{4}$ & $0.5 \mathrm{ml}$ & $--\cdot--\cdot$ & -- & 0 \\
\hline 10 & - & $0.5 \mathrm{ml}$ & $\ldots-\cdots$ & -- & 0 \\
\hline
\end{tabular}


Table 20. - Leukocyte response in mice 3 hours afer intraperitoneal injections of Candida albicans and 1.0 per cent Plurafac 826 - Candida albicans

\begin{tabular}{|c|c|c|c|c|}
\hline $\begin{array}{l}\text { Substance } \\
\text { Injected }\end{array}$ & $\begin{array}{c}\text { Specific } \\
\text { Time in } \\
\text { Hours }\end{array}$ & $\begin{array}{l}\text { Peritoneal } \\
\text { Fluid } \\
\text { Collected }\end{array}$ & Leukocyte/ $\mathrm{mm}^{3}$ & $\begin{array}{c}\text { Total } \\
\text { Leukocytes }\end{array}$ \\
\hline 0 & 0 & $0.30 \mathrm{cc}$ & 13,300 & $3,990,000$ \\
\hline 0 & 0 & $0.29 \mathrm{ce}$ & 9,750 & $2,827,500$ \\
\hline 0 & 0 & $0.25 \mathrm{cc}$ & 14,700 & $3,675,000$ \\
\hline Phys. saline & 3 & $0.35 \mathrm{cc}$ & 12,000 & $4,200,000$ \\
\hline Phys. saline & 3 & $0.41 \mathrm{cc}$ & 12,100 & $4,961,000$ \\
\hline Phys. saline & 3 & $0.32 \mathrm{cc}$ & 15,450 & $4,944,000$ \\
\hline $2 \times 10^{7}$ c. albicans & 3 & $0.68 \mathrm{cc}$ & 17,600 & $11,968,000$ \\
\hline $2 \times 10^{7}$ c. albicans & 3 & $0.70 \mathrm{cc}$ & 19,750 & $13,825,000$ \\
\hline $2 \times 10^{7}$ c. albicans & 3 & $0.40 \mathrm{cc}$ & 25,450 & $10,180,000$ \\
\hline
\end{tabular}


Table 20. - Continued

\begin{tabular}{|c|c|c|c|c|}
\hline $\begin{array}{l}\text { Substance } \\
\text { Injected }\end{array}$ & $\begin{array}{c}\text { Specific } \\
\text { Time in } \\
\text { Hours }\end{array}$ & $\begin{array}{l}\text { Peritoneal } \\
\text { Fluid } \\
\text { Collected }\end{array}$ & Leukocytes $/ \mathrm{mm}^{3}$ & $\begin{array}{c}\text { Total } \\
\text { Leukocytes }\end{array}$ \\
\hline $\begin{array}{l}2 \times 107 \text { C. albicans } \\
+1.0 \% \text { Plurafac } 326\end{array}$ & 3 & $0.90 \mathrm{cc}$ & 3,050 & $2,745,000$ \\
\hline $\begin{array}{l}2 \times 10^{7} \text { C. albicans } \\
+1.0 \% \text { Piurafac } 826\end{array}$ & 3 & $1.10 \mathrm{cc}$ & 3,550 & $3,905,000$ \\
\hline $\begin{array}{l}2 \times 10^{7} \mathrm{C} \text {. albicans } \\
+1.0 \% \text { Plurafac } 826\end{array}$ & 3 & $1.10 \mathrm{cc}$ & 1,200 & $1,320,000$ \\
\hline
\end{tabular}


Table 21. - Leukocyte response in mice 5 hours after intraperitoneal injection of Candida albicans and 1.0 per cent Plurafac B26 - Candida albicans

\begin{tabular}{|c|c|c|c|c|}
\hline $\begin{array}{l}\text { Substance } \\
\text { Injected }\end{array}$ & $\begin{array}{c}\text { Specific } \\
\text { Time in } \\
\text { Mours }\end{array}$ & $\begin{array}{l}\text { Peritoneal } \\
\text { Fluid } \\
\text { Collected }\end{array}$ & Leukocytes $/ \mathrm{mm}^{3}$ & $\begin{array}{c}\text { Total } \\
\text { Leukocytes }\end{array}$ \\
\hline Phys. saline & 5 & $0.20 \mathrm{cc}$ & 17,950 & $3,590,000$ \\
\hline Phys. saline & 5 & $0.23 c c$ & 16,480 & $3,790,000$ \\
\hline Phys. saline & 5 & $0.25 \mathrm{cc}$ & 16,600 & $4,150,000$ \\
\hline $2 \times 10^{7}$ c. albicans & 5 & $0.50 \mathrm{cc}$ & 22,450 & $11,225,000$ \\
\hline $2 \times 10^{7}$ c. albicans & 5 & $0.45 \mathrm{cc}$ & 19,600 & $8,820,000$ \\
\hline $2 \times 10^{7}$ c. albicans & 5 & $0.52 c c$ & 23,050 & $11,986,00$ \\
\hline
\end{tabular}


Table 21. - Continued

\begin{tabular}{|c|c|c|c|c|}
\hline $\begin{array}{l}\text { Substance } \\
\text { Injected }\end{array}$ & $\begin{array}{c}\text { Specific } \\
\text { Time in } \\
\text { Hours }\end{array}$ & $\begin{array}{l}\text { Peritoneal } \\
\text { Fluid } \\
\text { Collected }\end{array}$ & Leukocytes $/ \mathrm{mm}^{3}$ & $\begin{array}{c}\text { Total } \\
\text { Leukocytes }\end{array}$ \\
\hline $\begin{array}{l}2 \times 10^{7} \text { C. albicans } \\
+1.0 \% \text { Piurafac } 826\end{array}$ & 5 & $1.20 \mathrm{cc}$ & 10,000 & $12,000,000$ \\
\hline $\begin{array}{l}2 \times 10^{7} \mathrm{C} \text {. albicans } \\
+ \text { Plurafac } \frac{1826}{86}\end{array}$ & 5 & $0.90 \mathrm{cc}$ & 10,750 & $9,675,000$ \\
\hline $\begin{array}{r}2 \times 107 \text { c. albicans } \\
+1.0 \% \text { Plurafac } B 26\end{array}$ & 5 & $0.70 \mathrm{cc}$ & 10,750 & $7,525,000$ \\
\hline
\end{tabular}


At 3 hours these leukocyte counts are lower than physiological saline counts; but at 5 hours these counts are very similar to those obtained from the injection of $2 \times 10^{7}$ Candida albicans alone.

A1so, surface-active agents increase the volume of fluids in the peritoneal cavity.

Differential leukocyte counts were made at 3 and 5 hours. These counts are recorded in Table 22. As with Fruhman's work, Iymphocytes and monocytes were grouped together because transitional forms and the Wright staining technique made differentiation difficult (49). Table 22 shows that non-pyrogenic saline does not stimulate the influx of neutrophiles -- the percentage remained near 2 per cent. An interesting fact, however, was that Candida albicans-Plurafac B26 and Candida albicans aione greatly increased the percentage of neutrophiles compared to eosinophiles and lymphocytes - monocytes. Another interesting observation was made upon examination of the tissues slides. The majority of Candida albicans organisms present in the peritoneal fluid at 3 and 5 hours were mycellal forms. Occasionally hyphal forms of the fungus were seen within leukocytes, but the scarcity of leukocytes containing Candida 
Table 22. - Leukocytes recovered from intraperitoneal cavities of mice injected with Candida albicans and 1.0 per cent Plurafac B26 - Candida albicans

\begin{tabular}{|c|c|c|c|c|c|c|}
\hline \multirow{2}{*}{$\begin{array}{l}\text { Substance } \\
\text { Injected }\end{array}$} & \multirow[t]{2}{*}{ Hours } & \multirow{2}{*}{$\begin{array}{l}\text { No. } \\
\text { Mice }\end{array}$} & \multirow{2}{*}{$\begin{array}{l}\text { Leukocytes } \\
\text { Counted }\end{array}$} & \multicolumn{3}{|c|}{ Leukocyte Percentage } \\
\hline & & & & $\begin{array}{l}\text { Lymphocytes- } \\
\text { Monocytes }\end{array}$ & Eosinophiles & Neutrophiles \\
\hline 0 & 0 & 3 & 300 & $98 \%$ & $1 \%$ & $1 \%$ \\
\hline Phys. saline & 3 & 3 & 300 & $98 \%$ & 0 & $2 \%$ \\
\hline $2 \times 10^{7}$ c. albicans & 3 & 3 & 300 & $52 \%$ & $2 \%$ & $46 \%$ \\
\hline $\begin{array}{l}2 \times 10^{7} \text { c. albicans } \\
+1.0 \% \text { pTurafac } B 26\end{array}$ & 3 & 3 & 300 & $32 \%$ & $2 \%$ & $66 \%$ \\
\hline Phys. saline & 5 & 3 & 300 & $93 \%$ & 0 & $2 \%$ \\
\hline $2 \times 10^{7}$ C. albicans & 5 & 3 & 300 & $43 \%$ & $3 \%$ & $54 \%$ \\
\hline $\begin{aligned} 2 \times 10^{7} \mathrm{C} & \text { : albicans } \\
& +1.0 \% \text { piurafac } \mathrm{B} 26\end{aligned}$ & 5 & 3 & 300 & $33 \%$ & $2 \%$ & $65 \%$ \\
\hline
\end{tabular}


albicans prevented an opsonic index study.

Representative tissue sections stained with periodic acid-Schiff solutions are pictured on Plates 1-8. Plates 1 and 2 show normal sections of the kidney and pancreas, respectively. Tissue sections of 10 animals injected intraperitoneally with $2 \times 10^{7}$ Candida albicans suspended in 1.0 per cent Plurafac 826 invariably showed infections of the pancreas but not of the kidney. Plate 3 shows the organisms invading the cellular structure of the pancreas from the periphery inward, while plate 4 shows a complete destruction of acini with many hyphal elements present.

Sections of the pancreas and kidneys of mice that received only $2 \times 10^{7}$ Candida albicans did not show infections in these organs. However, Candida organisms were observed in connective $t$ issue near the pancreas (P1ate 5).

Mice that received an overwhelming number of Candida albicans $\left(6.7 \times 10^{8}\right)$ died within 24 hours. Sections showed massive infection of the pancreas and kldneys (Plates $6,7,8)$. The kidney usually contained several foci of infection from which hyphal strands radiated. Table 23 summarizes the tissue section data. An 


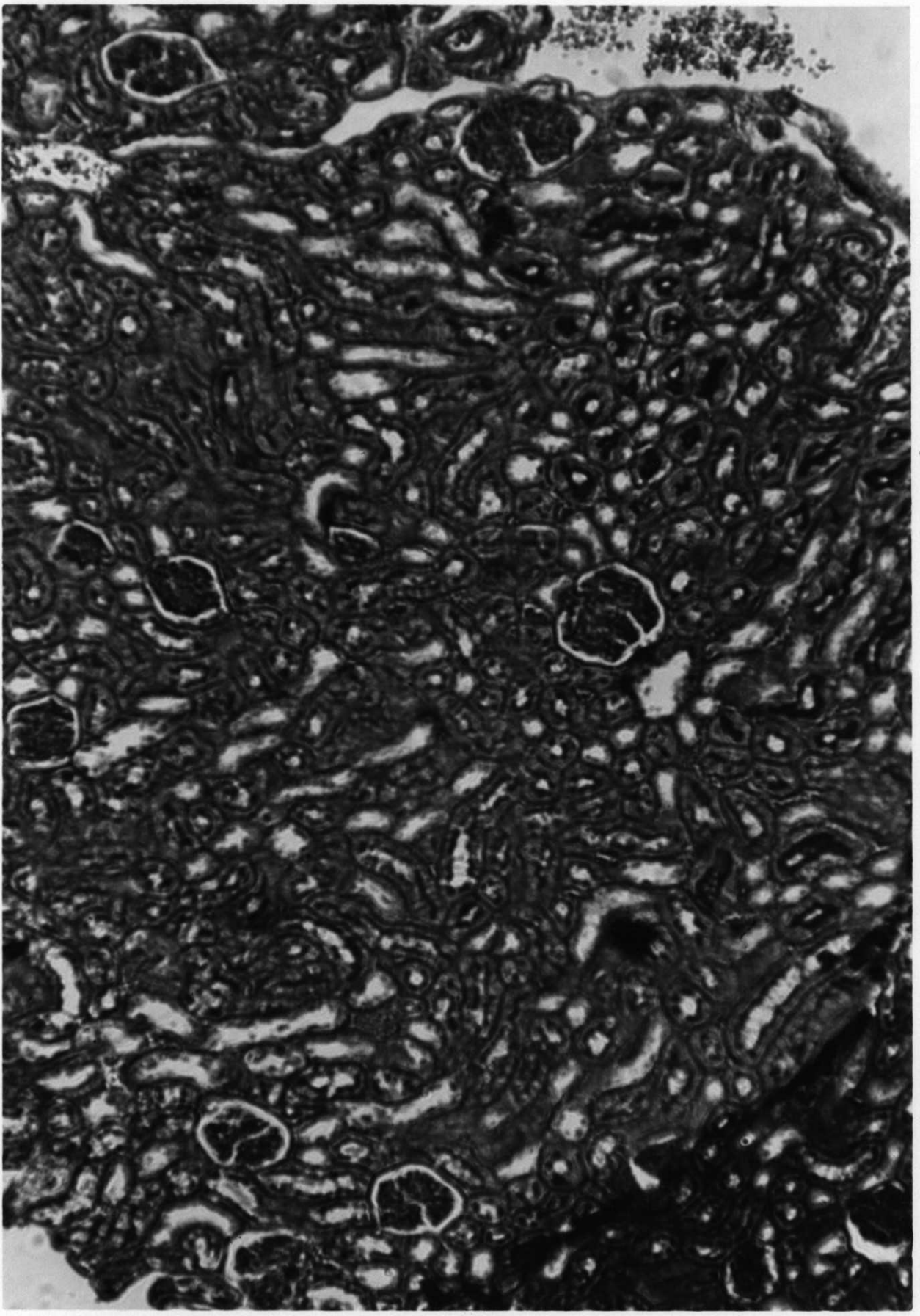

Plate 1. - Section of a normal white Swiss mouse kidney. (X100; periodic acid - Schiff method) 


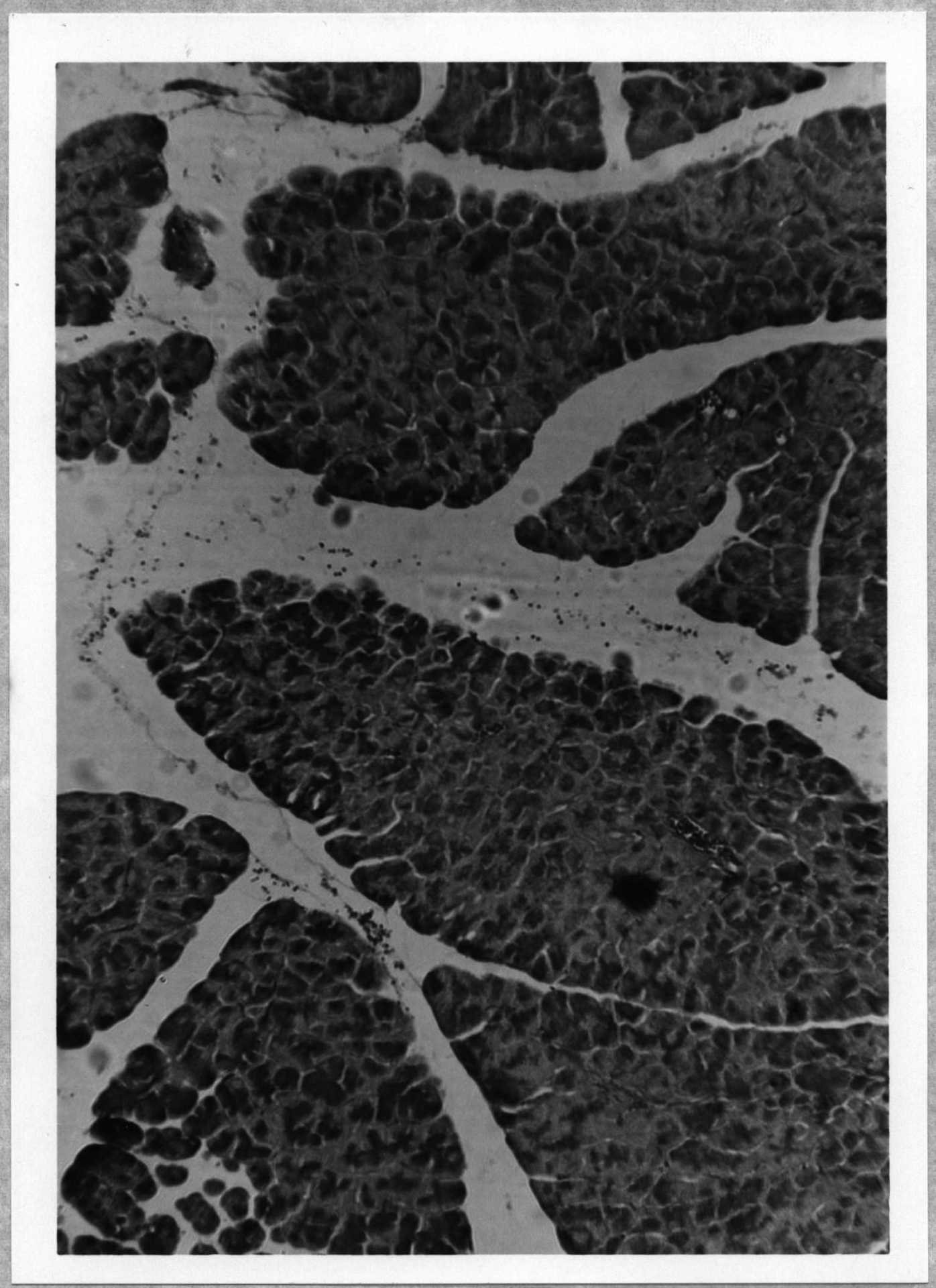

Plate 2. - Section of a normal white Swiss mouse pancreas. ( $\times 100$; periodic acid - Schiff method) 


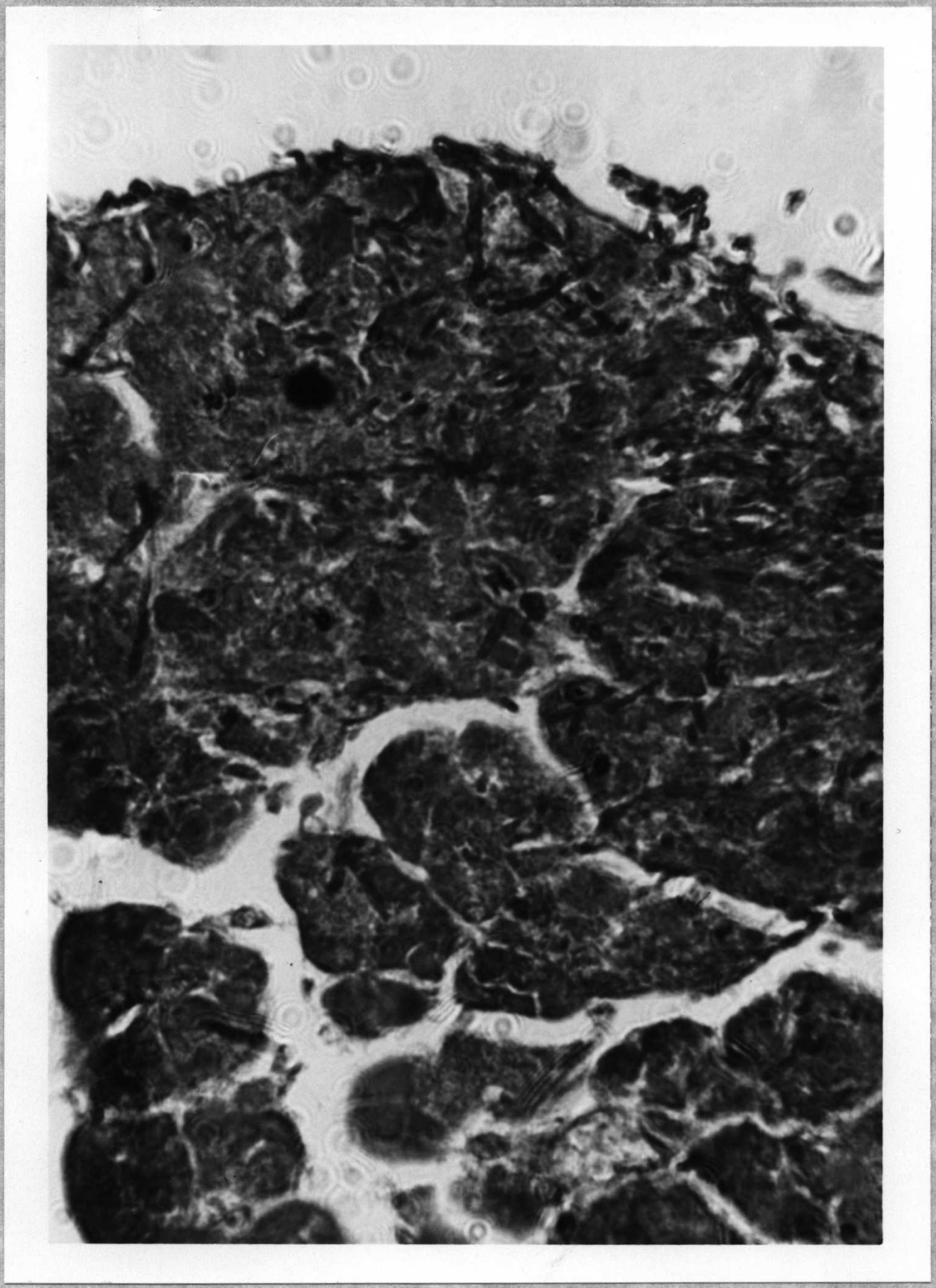

Plate 3. - Invasion of pancreas by Candide albicens suspended in 1.0 per cent Plurafac B26. 24 hour Infection. ( $\times 450$, perfodic acid - Schiff method) 


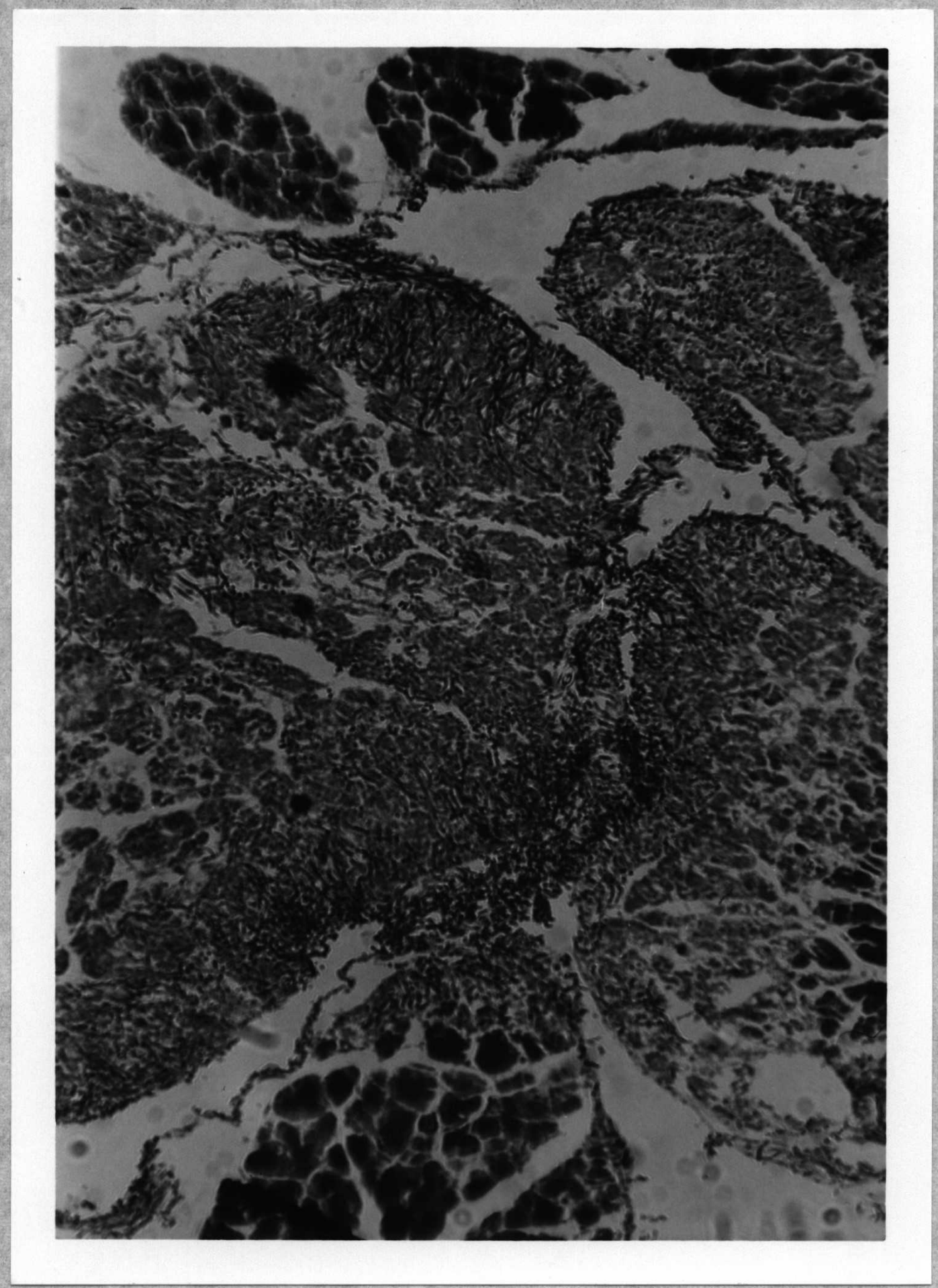

Plate 4. - Destruction of pancreas by Candida albicans suspended in 1.0 per cent Plurafac $326 .-24$ hour infection. ( $\times 100$; periodic acid - Schiff method) 


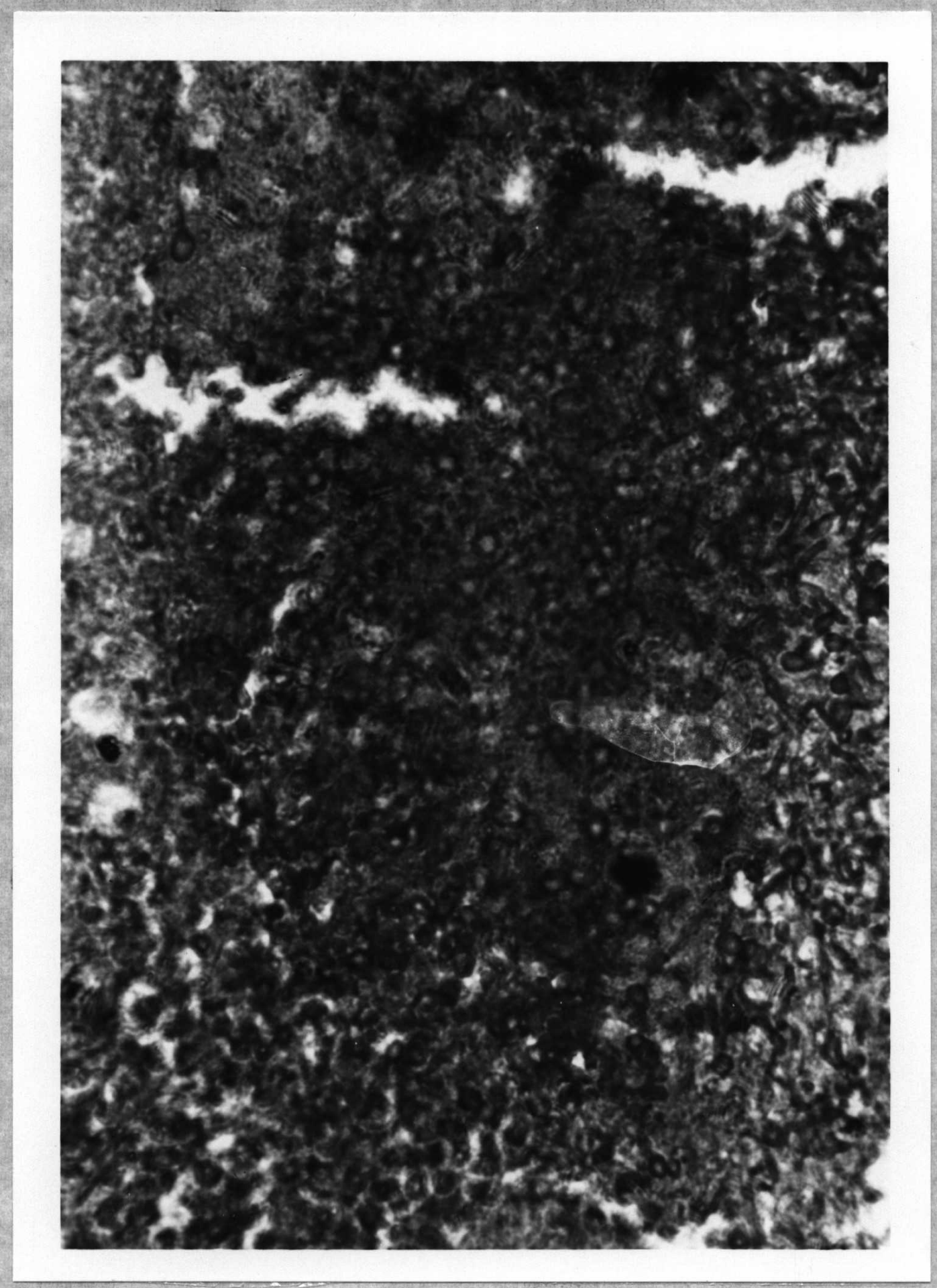

Plate 5. - Invasion of connective tissue near pancreas 24 hours after intraperitoneal injection of $2 \times 107$ Candida albicans. ( $\times 450$; periodic acid- Schiff method) 


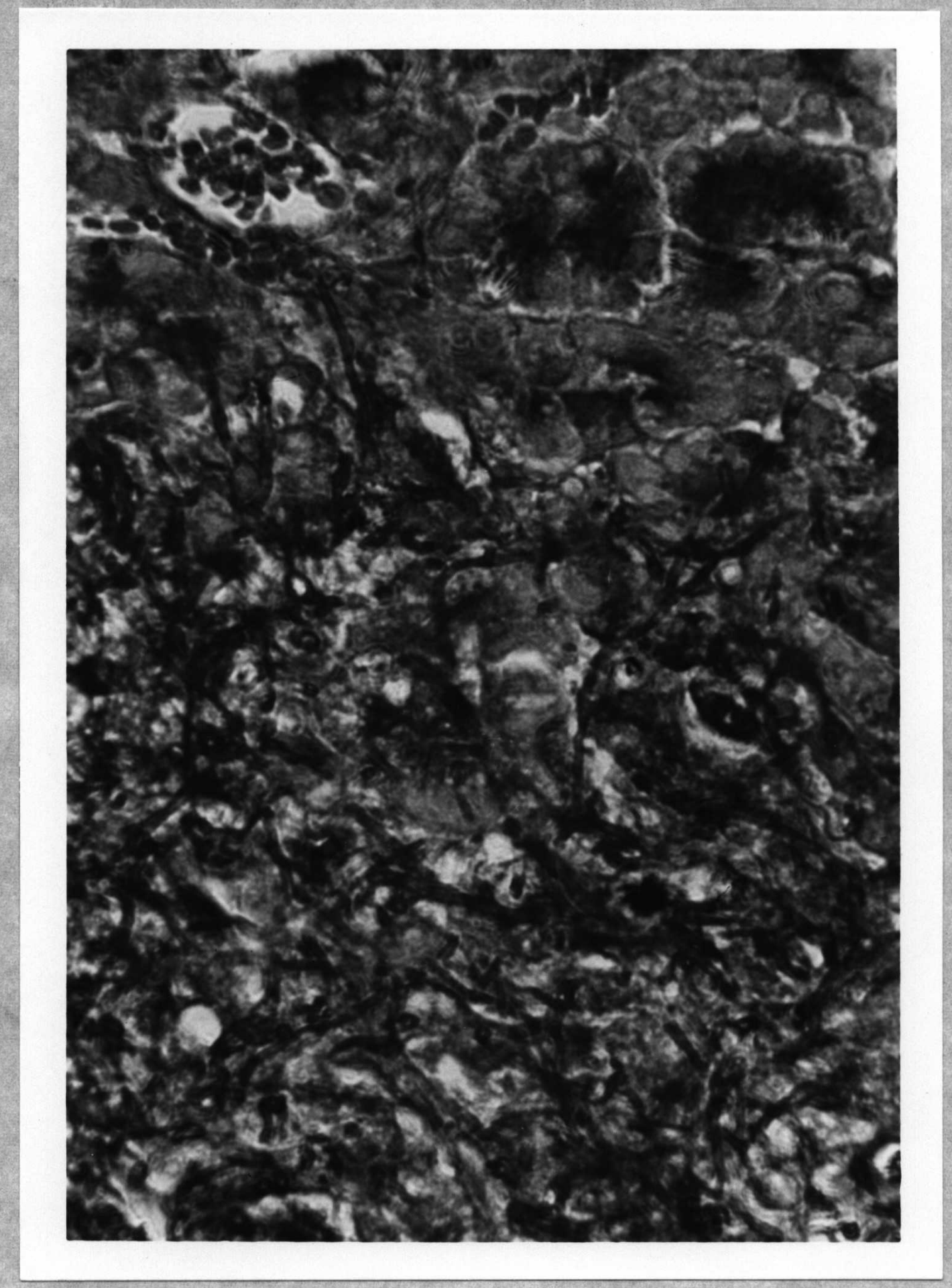

Plate 6. - Massive invasion of pancreas 24 gours efter intraperitoneal injection of $6.7 \times 10^{8}$ Candida albicans. ( $\times 450$; periodic acid Schiff method) 


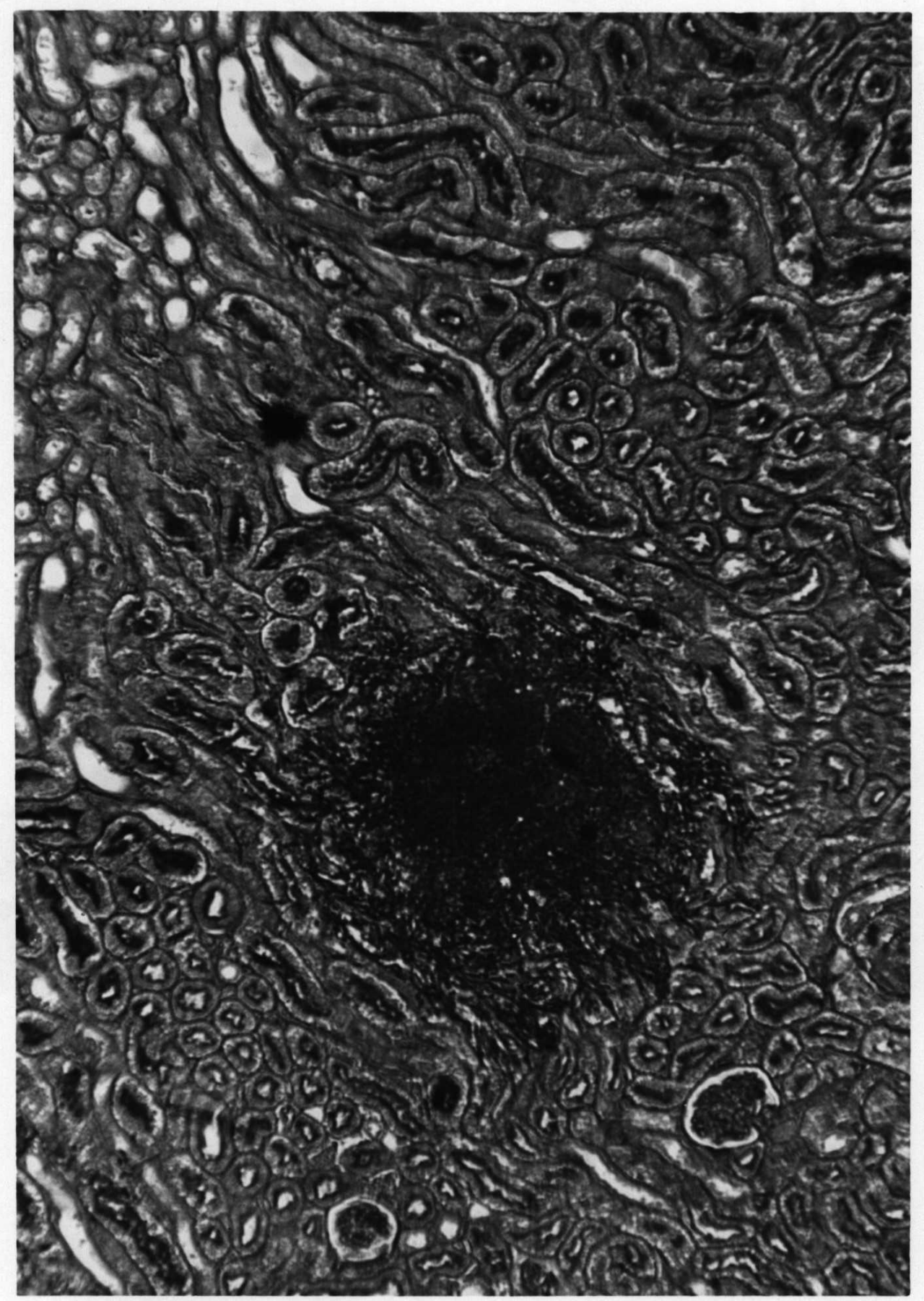

Plate 7. - Typical lesion of kidney 24 hours after intraperitoneal injection of $6.7 \times 10^{8}$ Candida al bicans. ( $\times 100$; periodic acid - Schiff method) - 


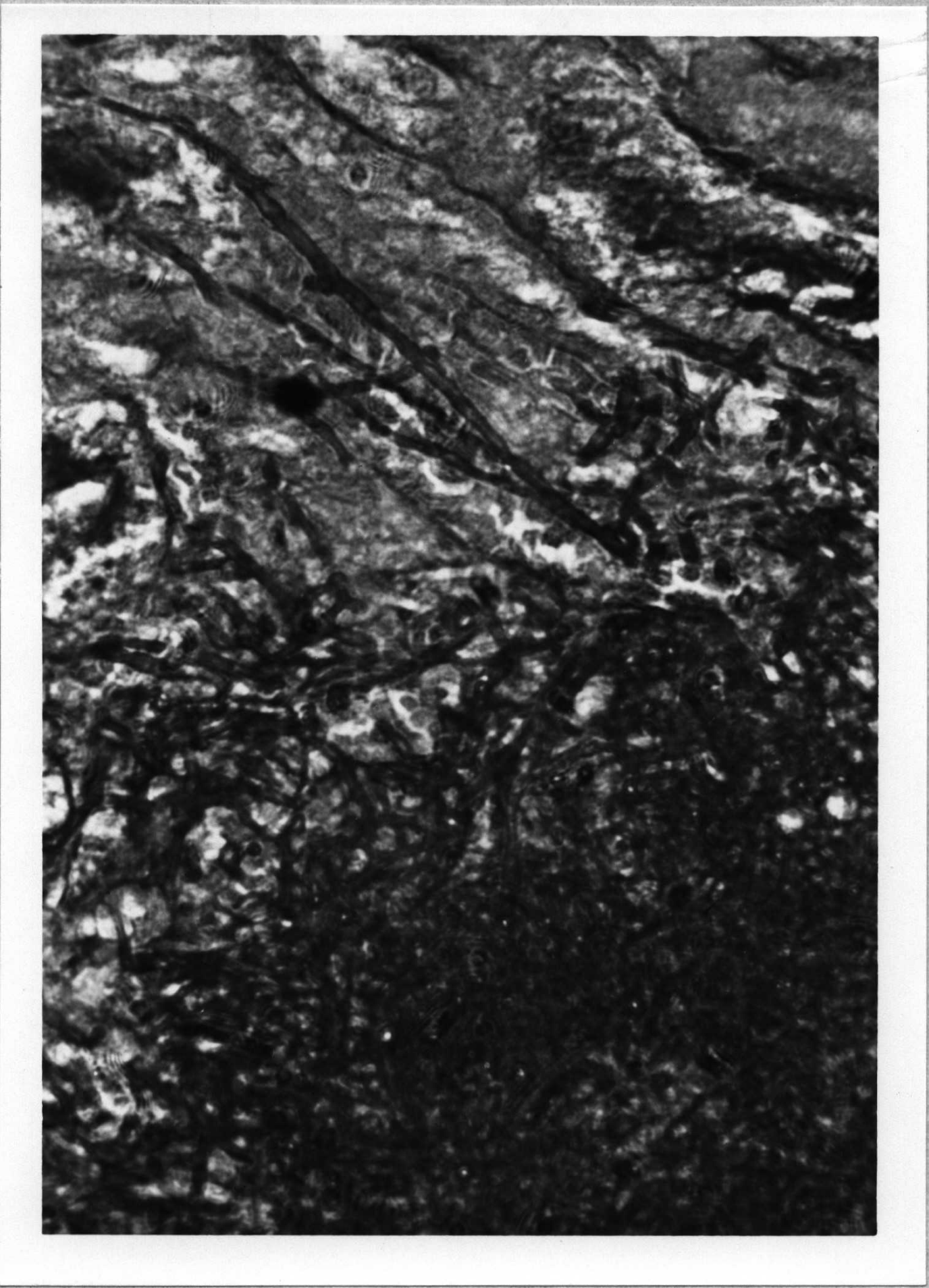

Plate 8. - Spreading hyphae in kidneys 24 hours after intraperitoneal injection of $6.7 \times 10^{8}$ Candida albicans. ( $\times 450$; periodic acid - Schiff method) 
Table 23. - Invasion of pancreas and kidneys of white Swiss mice by Candida albicans

\begin{tabular}{|c|c|c|c|c|c|}
\hline $\begin{array}{r}\text { Substance } \\
\text { Injected }\end{array}$ & $\begin{array}{l}\text { No. } \\
\text { Mice }\end{array}$ & $\begin{array}{l}\text { Time } \\
\text { Trial }\end{array}$ & $\begin{array}{l}\text { No. } \\
\text { Dead }\end{array}$ & Pancreas Invaded & Kidneys Invaded \\
\hline $2 \times 10^{7}$ C. albicans & 10 & $24 \mathrm{hr}$ & 0 & 0 & 0 \\
\hline $\begin{array}{l}2 \times 10^{7} \text { C. } \frac{\text { albicans }}{+1.0 \% \text { Plurafac } 826}\end{array}$ & 10 & $24 \mathrm{hr}$ & 10 & 10 & 0 \\
\hline $6.7 \times 010^{8}$ C. albicans & 10 & $24 \mathrm{hr}$ & 10 & 10 & 10 \\
\hline
\end{tabular}


Interesting observation was that there were no infections of the kidneys of female white Swiss mice injected with $2 \times 10^{7}$ Candida albicans plus 1.0 per cent Plurafae B26, but there were infections of the kidneys of mice injected with $6.7 \times 10^{8}$ organisms.

Also mice that received $2 \times 10^{7}$ Candide albicans plus 1.0 per cent Plurafac 326 had massive infections of the pancrees, but mice that received only $2 \times 10^{7}$ Candide albicans organisms did not have these infections.

Results from the blood cultures from mice injected with Candfda albicans plus Plurafac 026 were as follows: (a) no Candida aibicans organisms were isolated from teil blood, (b) no cendida albicans organisms were isolated from heart blood cultures efther from mice that had died naturally, or from mice sacrificed at 24 hours. No Candida organisms were isolated within 24 hours from mice injected with $2 \times 10^{7}$ organisms, but Candida albicans were isolated from tail blood cultures at 12 hours and from heart blood cultures of mice injected with $6.7 \times 10^{8}$ cells. This is summarized in Table 24 . 
Table 24. - Tail and heart blood cultures of Candida albicans and Plurafac 826 - Candida albicans mixtures

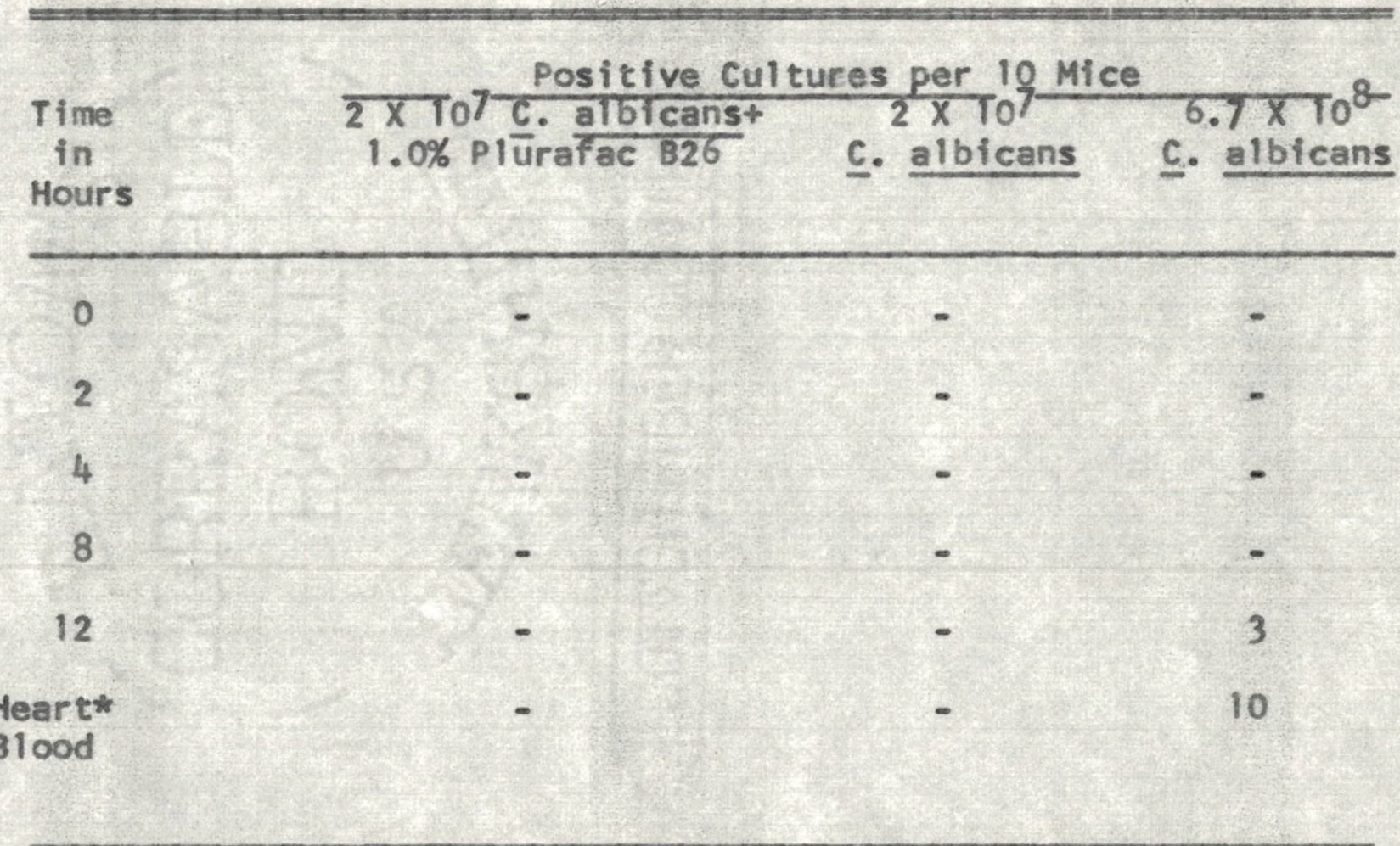

*Observation period -24 hours. Blood secured at 24 hours or at time of death 


\section{DIsCusSION}

The most striking effect of injecting a non-lethal amount of surfactant ( 1.0 per cent) with a non-lethal number of Candida albicans $\left(2 \times 10^{7}\right.$ organisms) was the death of nearly all of the test animals within 2 or 3 days. If the amount of surfactant was decreased, and the number of organisms remained constant, the death rate decreased. These experiments showed that a smaller percentage of Plurafac B26, compared to the other surfactants, was necessary to get a decreased L050. The descending order of effectiveness appeared to be Plurafac B26, Pluronic L62, Mulsor 224, and Polyethylene Glycol 400 Mono Laurate.

Since it was found that the mortality rate was a function of the percentage of surfactant used, it was decided to use a high percentage of surfactant 11.0 per cent) to determine the L050's of Candida albicans combined with the surfactants. When we compare the L050's of 1.0 per cent surfactant - Candida albicans to Candida albicans (controls), we see that Polyethylene Glycol 400 Mono Laurate decreased the LD50 by a factor of 20, Pluronic L62 by a factor of 26, Mulsor 224 by a factor of 30 , and 
Plurafac B26 by a factor of 82 . In both of these sets of experiments, then, Plurafac 326 most effectively lowers the LO50 of Candida albicans to white Swiss mice. Certain authors have shown that varfous agents increase the susceptibility of mice to Candida albicans, but a few people have shown the actual decrease of the L050. Salvin showed that the LO50 of Candida albicans suspended in 2.5 per cent gastric mucin was $2.2 \times 10^{7}$ organisms, but he did not state the LD50 of Candida albicans alone (50).

Christovao, however, stated that when Shigella and Salmonella species were injected intraperitoneally with deceresol-OT and sodium lauryl sulphate, the LO50's were 7-200 times smaller than the controls (51). The variation was due to differences in organisms and surfactants tested.

Candida utilis was used as a system control. Originally it was thought that possibly sheer numbers of organisms plus the before-mentioned surfactants could cause fatalities. We saw, however, that no fatalities occurred when Candida utilis was injected with surfactants. Therefore, the pathogenicity of the organisms was also a factor in the mouse fatalities. 
Since the L050's of the organisms grown in surfactant-Sabouraud media were not far removed from Candida albicans controls, it was decided not to pursue this part of the problem.

Fruhman reported that the peritoneal fluid in unstimulated rats contains less than 5 per cent neutrophiles (52). The remaining cells were mainly lymphocytes, monocytes and eosinphiles. He reported that sterile, non-pyrogenic saline failed to evoke a local neutrophile.

With this in mind, Tables 19, 20 and 21 show some interesting results. This work confirms that of Fruhman's; that is, non-pyrogenic saline does not elicit a positive neutrophilic response. When an antigenic substance is injected (Candida albicans) we get a vast increase in the number of leukocytes present, with a neutrophilic percentage of 40-60. This constitutes a definite positive response. But when 1.0 per cent Plurafac 826 is combined with the organisms, we find a decreased num. ber of leukocytes at 3 hours. At 5 hours the number of leukocytes approaches that of the Candida albicans control. In 1935 Miller and Castles observed that polymorphonuclear leukocytes did not begin to accumulate until after 3 hours following an intraperitoneal injection 
of gastric mucin and meningococei (53). Leukocyte numbers gradually increased until 9 hours when they were abundant. Eriolo et al. confirmed and enlarged upon the work of Miller and Castles (54). They observed a strong leukocyte response within 2.5-5 hours after injection with 50,000 staphylococci. When gastric mucin was combined with the organisms, the leukocyte response was depressed. They observed, however, that when leukocytosis was already present, mucin did not interfere with it and did not destroy leukocytes. An important element of their work demonstrated that bacterla were rapidly destroyed when bacteria plus gastric mucin were injected intraperitoneally into areas where leukocytosis already existed. Does Plurafac B26 initially inhibit a positive neutrophilia response? Tables 19,20 and 21 indicate that Plurafac 826 does decrease the number of leukocytes. Two factors are important: (a) the total number of leukocytes of mice receiving Plurafac B26 is lower than that of the controls, and (b) the percentage of neutrophiles present at 3 hours is much greater than 5 per cent. These data then, seem to indicate that a positive neutrophilfe response occurs by 3 hours, but that 
possibly Plurafac 826 destroys the leukocytes once they enter the cavity. By 5 hours the leukocytic counts approach that of the Candida albicans control. Probably the surfactant is diluted by this time and therefore is not lysogenic. The action of Plurafac 826 appears to be distinet from gastric mucin.

A common consensus of previous workers was that deaths of mice due to candidiasis was a result of kidney infections. Young showed that although many tissues may be initially infected with Candida albicans, the main foci of infection were the kidneys and pancreas (55). He also stated that the pancreas was the route of invasion of Candida albicans.

A study of tissue preparations revealed no invasion of the kidney when $2 \times 10^{7}$ Candida albicans organisms suspended in Plurafac B26 were injected, although sections showed massive invasion of the pancreas. Control animais $(2 \times 107$ Candida albicans $)$ did not show infections of the panereas or the kidneys after 24 hours. Invasion of the connective tissue was the only sign of Candida infection.

It is noteworthy that $6.7 \times 10^{8}$ organisms produced massive lesions in both kidneys and pancreas. 
Lesions of the kidney were observed throughout the medulla and cortex. Although Young (56) showed that infection was via the pancreas, I also observed a direct mycelial invasion of the kidney cortex.

These results demonstrate these facts: (a) mortality of mice is due ro Candida albicans infections, (b) Plurafac 826 increases the rate of infections of the pancreas, and (c) apparentiy early deaths of mice injected with Plurafac 826 - Candida albicans are due to pancreatic lesions.

A result difficult to explain is the absence of positive blood cultures, (either from tall blood or from heart blood) in animals injected with $2 \times 10^{7}$ Candida albicans suspended in Plurafac B26, and in animals injected with $2 \times 10^{7}$ Candida albicans (controls). Two factors may be linked to these results: (a) the suddenness of death of animals injected with Candida plus Plurafac B26, and (b) too few Candida albicans in the controls. Young reported that if $4 \times 10^{7}$ Candida albicans were injected intraperitoneally, 24 hours later the blood contained organisms (even if the culture was of low virulence) (57). Mankowski reported that blood from the tail vein contained Candida albicans 24 hours after intraperi- 
toneal injections (58). Since many of the mice injected with Plurafac B26 - Candida albicans mixtures died within 12-18 hours, possibly a systemic infection did not occur and therefore blood cultures were negative.

The positive blood cultures resulting from injection of $6.7 \times 10^{8}$ organisms also tends to show that a large number of organisms is necessary to get positive cuitures by 24 hours and to suggest that invasion of the kidney medulla may be via the bloodstream.

One wonders why the pancreas and the kidney are the foci of infection. The pancreas may yield to infection because of its thin capsule. Certainly one may not eliminate the possibility that surfactants affect the capsular material of the pancreas thus allowing infection to occur.

The reason that the kidney is often a focus of Candida albicans infection is not completly understood. Louria belleves the fungus grows in the renal tubular lumen and thus escapes host defenses (59): Andriole and Hasenclever believe that complement may be of value in inhibiting candidiasis $(60)$. Beeson and Rowly have shown that an anticomplementary substance (to the fourth component) is present in the kidney (61). They believe 
this substance is ammonia since this compound inactivates the fourth component of complement. Most bacterial lesions are in the medulla which is the principal site of ammonia formation. Perhaps the ammonia formed in the kidney inhibits complement action and allows the fungus invasion to occur.

Apparently, certain surfactants increase the susceptibility of mice to Candida albicans. The initial infection appears to be in the pancreas. Injection of Plurafac B26 - Candida albicans causes pancreatic lesions to appear and directly contributes to the mouse fatalities (no kidney lesions were seen). Infection by large numbers $\left(6.7 \times 10^{8}\right)$ of Candida albicans produces lestons in both the kidney and pancreas. The mechanism of this infection, however, is not understood. 


\section{SUMMARY}

The objectives of this thesis were twofold; firstly, to determine if certain surfactants would increase mouse susceptibility, to Candida albicans; and secondly, to determine the mechanism of action of surfactants.

Death rates were observed and L050's were calculated for various diltuions of Candida albicans suspended in 1.0 per cent solutions of Plurafac 826 , Polyethylene Glycol 400 Mono Laurate, Pluronic L62 and Mulsor 224. The effects of various percentages of surfactants combined with $2 \times 10^{7}$ Candida albicans organisms were al so ascertained. Peritoneal leukocyte counts, differential counts, tissue sections, and biood cultures were done to help determine the action of surfactants with regard to inciting infections.

The conclusions from these data are as follows:

(a) The non-ionic surfactants Plurafac B26, Polyethylene Glycol 400 Mono Laurate, Mulsor 224, and Pluronic L62 increase mouse susceptibility to Candida albicans.

(b) Plurafac B26 enhances mouse susceptibility to a greater degree than Polyethylene Glycol 
400 Mono Laurate. Pluronic L62 and Mulsor 224 are intermediate in effect.

(c) Plurafac 826 apparently enhances the invasiveness of Candida albicans possibly by initially destroying leukocytes in the peritoneal cavity.

(d) Death of mice injected with Candida albicans suspended in Plurafac B26 may be due to destruction of the pancreas.

Because certain non-ionic surfactants have been shown to increase the infectivity rate of Candida albicans in mice, these surfactants might possibly be a diagnostic aid in the identification of Candida albicans. 


\section{LITERATURE CITED}

1. Benham, R.W., J. Infect. Ois,. 49, 183-215 (1931).

2. Stoval, W.., and Pessin, S.. Amer. J. Pub. Health, 24, 594-602 (1934).

3. Fuentes, C.A., Schwarz, J., and Aboulafia, R., Mycopath. et Mycol. App1., 6, 176-181 (1951).

4. Solotorovsky, M., Ironson, E.J., Gregory, F.J., and Winsten, S., Antibiotics and Chemotherapy, 4. 165-168 (1954).

5. Mankowsk1, Z.T., Trans. of N.Y. Acad. of Sci., 19. 548-570 (1957).

6. Hasenclever, H.F., J. Bact., 78, 105-109 (1959).

7. Winner, H.I., J. Path. Bact. 79, 420-423 (1960).

8. Masenclever, loc. cit.

9. Mankowski, loc. cit.

10. Salvin, S.B., Cory, J.C., and Berg, M.D., J. Infect. Dis., 90, $177-182$ (1952).

11. Strauss, R.E.., and Kligman, A.M., J. Infect. Dis., $88,151(1952)$.

12. Seligmann, E., Proc. Soc. Expti. Biol. \& Med., 83. $778-781$ (1953).

13. Mankowski, loc. eft.

14. Seligmann, loc. cft.

15. Lourfa, D., Fallon, N., and Browne, H.G., J. Clin, Invest.. 39, 1435-1449 (1960).

16. Roth, F.J., Jr., Friedman, J., and Syverton, J.T., J. of Immunol., $78,122-127$ (1957). 
17. Schwartz, A.M., and Perry, J.W., Surface Active Agents, Interscience Publishers, Inc.. New York, N.Y., 1949, P.5.

18. Morris, G.E., J. Indust. Hyg. and Toxicol., 26, $175-178(1944)$.

19. Speel, H.C., J. Invest. Dermat., 6, 293-304 (1945).

20. Speel, ibid.

21. Schwartz, 1oc. clt.

22. Schwartz, op. cit.. pp. 202-203

23. Schwartz, ibld.

24. Dubos, R.W., and Middlebrook, G., J. Expt1. Med., 88, $81-88(1948)$.

25. Ward, M., Proc. Soc. Expt1. Biol. \& Med., 67, 527$528(1948)$.

26. Toennies, G., Gallant, D.L., Rahn, O., and Iske, B., J. Lab \& ciln. Med., 38, 163-165 (1951).

27. Baker, Z., Harrison, R.W., and MIIler, B.F., J. Expt1. Med., 74, $611-620(1941)$.

28. Achten, G., J. Invest. Dermat., 26, 389-397 (1956).

29. Knox, W.E., Auerbach, V.H., and Zarudnaya, K., J.

$=$ Bact., 58, $443-445$ (1949).

30. Baker, Z., Harrison, R.W., and MIller, B.F., J. Expt1. Med., 73, 249-271 (1941).

31. Petroff, S.A., Merman, M., and Palltz, L., Amer. Rev. Tuberc.. $44,738-756$ (1941).

32. Marwin, R.M., Bact. Proc., P. 55 (1956).

33. Marwin, R.M., Mycologia, 51, $61-68$ (1959).

34. Christovao, Dacto De Almeida, Proc. Soc. Expt1. Biol. c. Med., 94, 724-725 (1957). 
35. Amsterdam, $0 .$, and Schneierson, 0.0., Proc. Soc. Expt1. Biol. \& Med., 101, 396-398 (1959).

36. Goldhammer. H., and MeManus, W.K., Nature, 186, $317-318(1960)$.

37. Nissim, J.A., Nature, 187, 305-307 (1960).

38. Berry, L.J., Starr, R.W., III., and Haller, E., J. Bact., 57, $603-611$ (1949).

39. Di Luzio, N.R., and Wooles, W.R., Amer. J. Physiol., 206, $939-943$ (1964).

40. Woods, J.W., Manning, I.H., Jr., and Patterson, C.N., J.A.M.A., 145, 207-211 (1951).

41. Johnson, S.A.M., Arch. Dermat. \& Syph., 70, 49-58 (1954).

42. Greenwood, A.M., J.A.M.A., 89, 774-776 (1927).

43. Sutphin, A., Albright, F.. and Mccune, 0.J., J. Clin. Endoerinol.. 3, 625-634 (1943).

44. Martin, D.S., and Jones, C.P., J. Bact., 39, 609-630 $(1940)$.

45. Reed, L.J., and Muench, H., Amer. J. Hyg., 27, 493$497(1938)$.

46. Fruhman, G.J., Proc. Soc. Expt1. Biol. \& Med., 102, $423425(1960)$.

47. Young, G., J. Infect. Dis., 102, 114-120 (1958).

48. Marwin, R.M., Mycopath. et Mycol. Appl. 18, 259263 (1962).

49. Fruhman, 10c. cit.

50. Salvin, loc. cit.

51. Christovao, loc. clt.

52. Fruhman, 1oc. cit. 
53. Miller, C.P., and Castles, R., J. Infect. Dis., 58, 263-276 (1935).

54. Erioll, N., Lewis, M.N., and Harker, E., Proc. Soc. Expt1. Biol. \& Med., 59, 273-278 (1945).

55. Young, loc. cit.

56. Young, 1oc. clt.

57. Young, 1oc. cit.

58. Mankowski, 1oc. cit.

59. Louria, 1oc. cit.

60. Andriole, V., and Hasenclever, H.F., Yale J. Biol. Med., 35, 96-112 (1962).

61. Beeson, P.B., and Rowley, D., J. Expt1. Med., 110 , $685-697$ (1959). 